\title{
Development of $\mathrm{Ag} / \mathrm{MnCeOx}$ catalysts synthesized with ethanol or water for $\mathrm{HCHO}$ decomposition at ambient temperature
}

Article

Accepted Version

Creative Commons: Attribution-Noncommercial-No Derivative Works 4.0

Huang, Q., Qiu, H., Ye, L., Yang, B., Tao, T., Zhao, Y., Chen, M. and Yang, H. (2020) Development of $\mathrm{Ag} / \mathrm{MnCeOx}$ catalysts synthesized with ethanol or water for $\mathrm{HCHO}$ decomposition at ambient temperature. Materials Chemistry and Physics, 241. 122372. ISSN 0254-0584 doi:

https://doi.org/10.1016/j.matchemphys.2019.122372 Available at https://centaur.reading.ac.uk/87108/

It is advisable to refer to the publisher's version if you intend to cite from the work. See Guidance on citing.

To link to this article DOI: http://dx.doi.org/10.1016/j.matchemphys.2019.122372

Publisher: Elsevier

All outputs in CentAUR are protected by Intellectual Property Rights law, including copyright law. Copyright and IPR is retained by the creators or other copyright holders. Terms and conditions for use of this material are defined in the End User Agreement. 


\section{www.reading.ac.uk/centaur}

\section{CentAUR}

Central Archive at the University of Reading

Reading's research outputs online 


\title{
Development of $\mathrm{Ag} / \mathrm{MnCeO}_{\mathbf{x}}$ catalysts synthesized with ethanol or water for $\mathrm{HCHO}$ decomposition at ambient temperature
}

\author{
Qiong Huang ${ }^{1, *}$, Hua Qiu ${ }^{1}$, Lijihong Ye ${ }^{1}$, Bo Yang ${ }^{1}$, Tao Tao ${ }^{1}$, Yunxia \\ Zhao $^{1}$, Mindong Chen ${ }^{1}$ and Hong Yang ${ }^{1,2, *}$
}

1 Jiangsu Collaborative Innovation Center of Atmospheric Environment and Equipment Technologies, Jiangsu Key Laboratory of Atmospheric Environmental Monitoring \& Pollution Control, School of Environmental Science \& Engineering, Nanjing University of Information Science \& Technology, Nanjing 210044, China;

2 Department of Geography and Environmental Science, University of Reading, Whiteknights, Reading, RG6 6AB, UK

*Corresponding author 1: Dr. Qiong Huang

School of Environmental Science and Engineering, Nanjing University of Information Science \& Technology, Nanjing 210044, China

Address: No. 219 Ningliu Road, Nanjing University of Information Science \& Technology, School of Environmental Science and Engineering, 210044, Nanjing, China

E-mail: hqhaixia@163.com (Q.H.)

Tel: $+862558731090 \quad$ Fax: +862558731090

*Corresponding author 2: Dr. Hong Yang

Department of Geography and Environmental Science, University of Reading, Whiteknights, Reading, RG6 6AB, UK

E-mail: hongyanghy@gmail.com (H. Y.)

Tel: $+44(0) 1183787750$ 


\title{
Development of $\mathrm{Ag} / \mathrm{MnCeO}_{\mathrm{x}}$ catalysts synthesized with ethanol or water for HCHO decomposition at ambient \\ temperature
}

\begin{abstract}
Formaldehyde, one of important pollutants in the indoor air, has received increasing attention due to damage to human health. To mitigate formaldehyde pollution, $\mathrm{MnCeO}_{\mathrm{x}}$ mixed oxides were synthesized by solvothermal method with different solvents and complexing agents, including water or ethanol, and citric acid or glycol, and these catalysts were investigated to catalytic oxidation of formaldehyde at ambient temperature under a real indoor environment, as a super low concentration of indoor formaldehyde $\left(1.0 \pm 0.5 \mathrm{mg} / \mathrm{m}^{3}\right)$ and the air under static condition. The result indicated that the $\mathrm{MnCeO}_{\mathrm{x}}$ catalysts prepared with ethanol exhibited higher activities than samples synthesized with $\mathrm{H}_{2} \mathrm{O}$. Structure and performance analysis by BET, XRD, SEM, TEM, TG, Raman, XPS, $\mathrm{H}_{2}-\mathrm{TPR}$, and $\mathrm{O}_{2}-\mathrm{TPD}$ displayed that the $\mathrm{MnCeO}_{\mathrm{x}}$ oxides synthesized with ethanol (instead of using water) greatly promoted the structure and reducibility, resulting in a high activity for $\mathrm{HCHO}$ degradation. More than $90 \%$ conversion for $\mathrm{HCHO}$ degradation was finished at $36 \mathrm{~h}$ and no deactivation could be detected by a series of tests. More importantly, the $\mathrm{MnCeO}_{\mathrm{x}}$ oxides supported by an increasing of $\mathrm{Ag}$ exhibited the increased activity. Promoting effect of Ag over the $\mathrm{MnCeO}_{\mathrm{x}}$ oxides indicated a strong interplay between $\mathrm{Ag}$ and $\mathrm{MnCeO}_{\mathrm{x}}$ greatly affected the property of $\mathrm{Ag} / \mathrm{MnCeO}_{\mathrm{x}}$ catalysts. The $\mathrm{HCHO}$ concentration could be decreased to less than $0.08 \mathrm{mg} / \mathrm{m}^{3}$ at $24 \mathrm{~h}$ over $2.0 \mathrm{wt} \% \mathrm{Ag} / \mathrm{MnCeO}_{\mathrm{x}}(\mathrm{E} / \mathrm{G})$. The performance improvement was ascribed to the high reducibility and high distribution of metallic silver, which could increase the surface active oxygen species and improve the oxygen mobility, and also could weaken the surface Mn-O bond.
\end{abstract}

Keywords: Catalytic oxidation; $\mathrm{HCHO}$ elimination; $\mathrm{MnCeO}_{\mathrm{x}} ; \mathrm{Ag}$; Ambient temperature 


\section{Introduction}

Exposure to indoor air pollution containing formaldehyde (HCHO) for a certain of period, even at a low concentration, can cause great damage to human health ${ }^{[1,2]}$, particularly in China ${ }^{[3,4]}$. Hence, strenuous efforts have been tried to reduce $\mathrm{HCHO}$, but it is difficult to completely reduce the concentration to meet the environmental regulations $\left(0.08 \mathrm{mg} / \mathrm{m}^{3}\right)$ due to that $\mathrm{HCHO}$ emits from building materials, furniture, and daily living equipment at all the time, especially at high room temperatures ${ }^{[5,6]}$. However, enormous efforts have been devoted to seeking a new kind of technologies or materials to remove indoor $\mathrm{HCHO}$. As one of the most effective way as physical adsorption and chemical reaction, catalytic oxidation of $\mathrm{HCHO}$ with low-temperature has been deemed as a potentially effective approach to decompose $\mathrm{HCHO}$ into $\mathrm{CO}_{2}$ and $\mathrm{H}_{2} \mathrm{O}{ }^{[7,8,9]}$. Especially in this technical session, multifarious catalysts, such as noble metal oxides ${ }^{[10]}$, transition metal oxides ${ }^{[11]}$, and even mixed or composite oxides have been identified as the core for complete decomposition of $\mathrm{HCHO}{ }^{[12]}$. Hence, a lot of experiments on the low-temperature catalytic oxidation have been conducted to bring about steady improvement in its activity and stability. It is a promising technology owing to no requirement of heating or extra energy to employ in the reactor, and the sufficient stability for HCHO degradation ${ }^{[13]}$.

Pt catalysts have been identified as the highest efficient catalyst for HCHO decompose at ambient temperature. Huang et al. ${ }^{[14]}$ applied a series of high activity catalysts over Pt loading prepared by sodium borohydride reduction, for instance $\mathrm{Pt} / \mathrm{TiO}_{2}{ }^{[15,16,17]}$, $\mathrm{Pt} / \mathrm{Al}_{2} \mathrm{O}_{3}, \mathrm{Pt} / \mathrm{MgO}, \mathrm{Pt} / \mathrm{ZrO}_{2}$ and $\mathrm{Pt} / \mathrm{CeO}_{2}$, in the decomposition of $\mathrm{HCHO}$ (10ppm). The result exhibited a nearly $100 \% \mathrm{HCHO}$ conversion with $0.1 \mathrm{wt} \% \mathrm{Pt} / \mathrm{TiO}_{2}$ at ambient temperature. Zhang et al. ${ }^{[18,19]}$ found that $\mathrm{FeO}_{\mathrm{x}}$ supported Pt could be synthesized by different methods, such as impregnation, colloid deposition and co-precipitation. The results of analysis indicated that the preparation methods markedly affected the structure and redox of $\mathrm{Pt} / \mathrm{Fe}_{2} \mathrm{O}_{3}$ and the outstanding activity of $\mathrm{Pt} / \mathrm{Fe}_{2} \mathrm{O}_{3}-\mathrm{CD}$ can achieve a $100 \%$ conversion of $\mathrm{HCHO}(100-500 \mathrm{ppm})$ at $25^{\circ} \mathrm{C}$, probably due to the suitable interaction between $\mathrm{Pt}$ and $\mathrm{FeO}_{\mathrm{x}}$. Among of these $\mathrm{Pt}$ catalysts, $\mathrm{Pt} / \mathrm{TiO}_{2}$ have received the most attention owing to the highest activity for $\mathrm{HCHO}$ degradation under 
ambient temperature ${ }^{[20-26]}$. During the course of $\mathrm{HCHO}$ oxidation, $\mathrm{He}$ et al ${ }^{[27,22]}$ suggested that the conversion of surface formate species into $\mathrm{CO}$ adsorbed was the rate determining step. However, these formate species could be easily generated and then decomposed into $\mathrm{CO}$, which could be adsorbed on the surface, and then these $\mathrm{CO}$ could be oxidized into $\mathrm{CO}_{2}$ by $\mathrm{O}_{2}$ again. Therefore, the $\mathrm{Pt} / \mathrm{TiO}_{2}$ could display higher activity than $\mathrm{TiO}_{2}$ supported $\mathrm{Pd}, \mathrm{Au}$ and $\mathrm{Rh}$. In the meantime, other series of noble metal catalysts, including $\mathrm{Pt} / \mathrm{TiO}_{2} / \mathrm{Al}_{2} \mathrm{O}_{3}{ }^{[20]}, \mathrm{Au} / \mathrm{CeO}_{2}{ }^{[28,29,30]}, \mathrm{Pt} / \mathrm{SiO}_{2}{ }^{[31]}, \mathrm{Au} / \gamma-\mathrm{Al}_{2} \mathrm{O}_{3}{ }^{[12]}$ were synthesized by different methods for catalytic oxidation of $\mathrm{HCHO}$ and these catalysts exhibited higher activities than other transition metal oxides.

Based on the economic viewpoints, improving activity with transition metal oxides is more challenging to catalytic decomposition of low concentration of $\mathrm{HCHO}$, even 1 ppm, and then, make it less than indoor $\mathrm{HCHO}$ pollution regulation $\left(0.08 \mathrm{mg} / \mathrm{m}^{3}\right)$. But in fact, the effectiveness of the removal catalysts was confined to the decreasing activity due to their oxidation capacities without supplemental energy. For example, He et al ${ }^{\text {[32] }}$ developed porous nanomaterials with manganese oxide (K-OMS-2) for HCHO degradation, which were successfully prepared by the soft chemistry route. The result indicated that larger accessible pore channels could supply higher activity than nanorods. But only $64 \%$ conversion of $\mathrm{HCHO}$ could be decomposed at $100^{\circ} \mathrm{C}$ on $\mathrm{K}$ OMS-2 nanoparticles. Shen et al. ${ }^{[33,34]}$ reported that $\mathrm{MnO}_{\mathrm{x}}-\mathrm{CeO}_{2}$ catalysts with $\mathrm{Mn} /(\mathrm{Mn}+\mathrm{Ce})=0.5$ showed the highest activity, more than $90 \%$ conversion for $\mathrm{HCHO}$ degradation was achieved at $90^{\circ} \mathrm{C}$ due to $\mathrm{MnO}_{\mathrm{x}}-\mathrm{CeO}_{2}$ solid solution, which could promote the low-temperature reducibility. Qu et al. ${ }^{[35]}$ found that the sample of Ag/SBA-15 catalysts synthesized by post-grafting showed the higher dispersion of metal oxides, a smaller particle size of silver and better activity for catalytic oxidation of $\mathrm{HCHO}$. But, the oxidation temperature with more $90 \%$ conversion for $\mathrm{HCHO}$ is 100 ${ }^{\circ} \mathrm{C}$ higher than $\mathrm{Ag} / \mathrm{SBA}-15$ catalysts. In addition, some researchers have studied these transition metal oxides, including mesoporous $\mathrm{MnO}_{\mathrm{x}}[34,36,37,38], \mathrm{Ag} / \mathrm{CeO}_{2}{ }^{[39]}$, $\mathrm{Ag} / \mathrm{CeO}_{2}-\mathrm{MnO}_{\mathrm{x}} / \mathrm{SiO}_{2}{ }^{[40]}, \mathrm{Ag} / \mathrm{MCM}-41^{[41]}, \mathrm{MnO}_{\mathrm{x}}-\mathrm{SnO}_{2 \mathrm{a}}{ }^{[42]}, \mathrm{Co}-\mathrm{Mn}$ oxide ${ }^{[43]}$, to catalytic degradation of $\mathrm{HCHO}$ at ambient temperature.

According to previous studies mentioned above, the preparation method, solvents and 
metal oxides of catalysts are important factors affecting the activity for $\mathrm{HCHO}$ oxidation. However, as far as I know that there are still very few reports about transition metal oxides to catalytic oxidation of $\mathrm{HCHO}$ under a real indoor environment, as a super low concentration of indoor formaldehyde, even $1.0 \pm 0.5 \mathrm{mg} / \mathrm{m}^{3}$, and the air under static condition. Compared with the high concentration and flowing state of $\mathrm{HCHO}$, it was completely different and it always took a long time to complete catalytic oxidation, such as one or two days. Therefore, a series of $\mathrm{MnCeO}_{\mathrm{x}}$ and $\mathrm{Ag} / \mathrm{MnCeO}_{\mathrm{x}}$ were prepared by solvothermal method with the different solvents, including water and ethanol. The properties of these catalysts, including oxidation activity and stability, were investigated to catalytic degradation of a low concentration of $\mathrm{HCHO}$. Owing to the super low $\mathrm{HCHO}$ concentration, the reaction product of carbon dioxide cannot be effectively measured. In order to inquiry the impacts of different solvents on the redox properties, structure, and stability, the physical and chemical properties of these catalysts were characterized.

\section{Experimental}

\subsection{Syntheses}

$\mathrm{MnCeO}_{\mathrm{x}}$ catalysts with $\mathrm{Mn} /(\mathrm{Mn}+\mathrm{Ce})=0.8$ were synthesized by solvothermal method with using of water (W) or ethanol (E). Cerium nitrate and manganous nitrate were mixed and added in deionized water or ethanol with a sustained stirring. And then, a kind of complexing agent, such as citric acid (C) or glycol (G) was added into the solution with the molar ratio of complexing agents to metal ion as 0.17 . Then, the temperature of solution was set to $60^{\circ} \mathrm{C}$ with stirring continuously until sol. After that, the sol was moved to a Teflon-lined autoclave and heated with $120{ }^{\circ} \mathrm{C}$ and $24 \mathrm{~h}$. The result samples were dried and calcined with $550^{\circ} \mathrm{C}$ and $7 \mathrm{~h}$. The prepared samples were recorded as $\mathrm{MnCeO}_{\mathrm{x}}(\mathrm{W} / \mathrm{C}), \mathrm{MnCeO}_{\mathrm{x}}(\mathrm{W} / \mathrm{G}), \mathrm{MnCeO}_{\mathrm{x}}(\mathrm{E} / \mathrm{C})$ and $\mathrm{MnCeO}_{\mathrm{x}}(\mathrm{E} / \mathrm{G})$. For comparison, $\mathrm{MnCeO}_{\mathrm{x}}$ supported with $\mathrm{Ag}$ were synthesized by wet impregnation method. The powders of $\mathrm{MnCeO}_{\mathrm{x}}$ were dropped into the silver nitrate solution and heated. And then, the $\mathrm{Ag} / \mathrm{MnCeO}_{\mathrm{x}}$ were dried and calcined with $550{ }^{\circ} \mathrm{C}$ and $2 \mathrm{~h}$. The different loading of $\mathrm{Ag}$ over $\mathrm{Ag} / \mathrm{MnCeO}_{\mathrm{x}}$ catalysts were fabricated following the similar procedure to that of different concentration of silver nitrate solution. 


\subsection{Characterizations}

The textural properties were determined by $\mathrm{N}_{2}$ adsorption/desorption at $77.3 \mathrm{~K}$ using an automated gas sorption analyzer (ASAP-2020, Micromeritics Instrument Corporation, USA). Specific surface area (BET) was measured by using of BET and $\mathrm{BJH}$ methods on the basis of $\mathrm{N}_{2}$ adsorption-desorption isotherms in the relative pressure $\left(\mathrm{P} / \mathrm{P}_{0}\right)$ of 0.08-1.0. X-ray diffraction (XRD) measurement was carried out using D/max$\mathrm{RB}$ X-ray diffractometer with $\mathrm{Cu} \mathrm{K \alpha}$ radiation $(40 \mathrm{kV}$ and $30 \mathrm{~mA})$ and recorded between $10^{\circ}$ and $80^{\circ}(2 \theta)$ at a step of $5 \% \mathrm{~min}$. The characterization of scanning electron microscopy (SEM) was observed with SU1510 apparatus to obtain the morphology of these catalysts. High-resolution transmission electron microscopy (HRTEM) was taken with a microscope at an acceleration voltage of $200 \mathrm{kV}$. Temperature-programmed reduction of hydrogen $\left(\mathrm{H}_{2}-\mathrm{TPR}\right)$ and $\mathrm{O}_{2}$ temperature programmed desorption $\left(\mathrm{O}_{2}-\mathrm{TPD}\right)$ were performed in an AutoChem 2920 instrument (Micromeritics, USA) and embed in a quartz reactor, equipped with the thermal conductivity detector ( TCD). The samples with 40-60 meshes were embed in the U-type quartz reactor. At first, 50 mg samples were pretreated by using helium gas at $105^{\circ} \mathrm{C}$ for $30 \mathrm{~min}$, and then cooled down to 40 ${ }^{\circ} \mathrm{C}$ in the helium gas. For $\mathrm{H}_{2}-\mathrm{TPR}$, the samples were reduced by the $5 \% \mathrm{H}_{2} / \mathrm{Ar}(50$ $\mathrm{ml} / \mathrm{min}$ ) from 60 to $800{ }^{\circ} \mathrm{C}$ at a heating rate of $10{ }^{\circ} \mathrm{C} / \mathrm{min}$. The $\mathrm{H}_{2}$ consumption was measured by the TCD detector. For $\mathrm{O}_{2}-\mathrm{TPD}, \sim 50 \mathrm{mg}$ samples were treated by $5 \% \mathrm{O}_{2} / \mathrm{Ar}$ (50 $\mathrm{mL} / \mathrm{min}$ ) for $30 \mathrm{~min}$. After that, these samples were purified with helium gas flow for $30 \mathrm{~min}$ to remove the physiosorbed $\mathrm{O}_{2}$ and stabilize the baseline. Immediately, these samples were heated from 50 to $800{ }^{\circ} \mathrm{C}$ with a heating rate of $10^{\circ} \mathrm{C} / \mathrm{min}$ in the helium stream $(50 \mathrm{~mL} / \mathrm{min})$ and the $\mathrm{O}_{2}$ desorption was detected by using the TCD detector. Raman spectroscopy were acquired on a Renishaw in Viat + Reflex spectrometer equipped with a CCD detector. The Raman spectra were excited by a visible $532 \mathrm{~nm}$ argon ion laser and collected in the range between 300 and $1000 \mathrm{~cm}^{-1}$ with a spectral resolution of $1 \mathrm{~cm}^{-1}$. The X-ray photoelectron spectroscopy (XPS) measurements were conducted on a Thermo Scientific $K$-Alpha equipped with Al $K \alpha$ radiation (1486.6 eV), operating at $84 \mathrm{~W}$ and energy pass of $40 \mathrm{eV}$. Binding energies were calibrated using $\mathrm{C} 1 \mathrm{~s}$ hydrocarbon peak at $284.6 \mathrm{eV}$. The actual $\mathrm{Ag}, \mathrm{Mn}, \mathrm{Ce}$ and $\mathrm{O}$ contents in these 
catalysts were determined by inductively coupled plasma optical emission spectrometry (ICP-OES, Varian 720-ES).

The samples were reduced by $\mathrm{H}_{2}$ before catalyst characterization of XPS and these catalysts were stored in sealed bags and not re-activated prior to XPS measurement. Thermal gravimetric analysis (TGA) experiments were conducted on the TGA/DSC simultaneous thermal analyzer (TGA/DSC 1/1600HT, Switzerland) at the range of 50 $500{ }^{\circ} \mathrm{C}$ at a heating rate of $20^{\circ} \mathrm{C} / \mathrm{min}$ at air atmosphere with an atmospheric pressure. The air flow rate was $40 \mathrm{~mL} / \mathrm{min}$.

\subsection{Activity measurements}

The activity and stability for $\mathrm{HCHO}$ decomposition over these catalysts at ambient temperature were detected in a glass reactor $(0.6 \times 0.6 \times 0.6 \mathrm{~m})$. Liquid formaldehyde $(37 \mathrm{wt} \%, 1.0 \mathrm{~mL})$ was injected into a petri dish first, and then was moved into the glass reactor and volatilized for a few minutes. When the initial concentration of $\mathrm{HCHO}$ was reached at $1.05 \pm 0.05 \mathrm{mg} / \mathrm{m}^{3}$, the petri dish was taken out and $1.0 \mathrm{~g}$ catalysts powder dispersed in another petri dish were set into this glass reactor, quickly. After that, when the initial concentration of $\mathrm{HCHO}$ still remained at $1.05 \pm 0.05 \mathrm{mg} / \mathrm{m}^{3}$ for three times, the glass reactor was sealed and the adsorption or oxidation reaction of HCHO was started, immediately. The concentration of $\mathrm{HCHO}$ was detected by a formaldehyde analyzer (PPM-400st) and the results could be carried out for $48 \mathrm{~h}$. The measurements were detected at every $12 \mathrm{~h}$ for three times. Stability tests for HCHO decomposition were performed for 144 or $192 \mathrm{~h}$ with the same condition.

\section{Results and discussion}

\subsection{Catalytic activity and stability of catalysts}

Fig. 1 exhibits the activity of catalytic oxidation or adsorption of HCHO over active carbon and $\mathrm{MnCeO}_{\mathrm{x}}$ catalysts with $\mathrm{Mn} /(\mathrm{Mn}+\mathrm{Ce})=0.8$, which have been confirmed to have a high activity ${ }^{[44]}$ but poor stability, including $\mathrm{MnCeO}_{\mathrm{x}}(\mathrm{W} / \mathrm{C})$ and $\mathrm{MnCeO}_{\mathrm{x}}(\mathrm{W} / \mathrm{G})$, In the blank experiment, $\mathrm{HCHO}$ concentration decreased slight from 1.022 to 0.908 $\mathrm{mg} / \mathrm{m}^{3}$ within $48 \mathrm{~h}$, indicating that the glass reaction exhibited a good sealing property and kept at a stable concentration. The active carbon exhibited a larger specific surface area $\left(950 \mathrm{~m}^{2} / \mathrm{g}\right)$, but displayed a certain amount of formaldehyde adsorption, with 
decreasing concentration from 1.071 to $0.48 \mathrm{mg} / \mathrm{m}^{3}$ over $48 \mathrm{~h}$. More surprisingly, the catalysts synthesized with ethanol exhibited higher activity than other catalysts prepared with water, indicating that these catalysts exhibited both adsorption and catalytic oxidation activity. Same as BET and SEM, the maximum HCHO decomposition of these catalysts decreased in the order: $\mathrm{MnCeO}_{\mathrm{x}}(\mathrm{E} / \mathrm{G})>$ $\mathrm{MnCeO}_{\mathrm{x}}(\mathrm{E} / \mathrm{C})>\mathrm{MnCeO}_{\mathrm{x}}(\mathrm{W} / \mathrm{C})>\mathrm{MnCeO}_{\mathrm{x}}(\mathrm{W} / \mathrm{G})$ at ambient temperature. The HCHO conversion of $\mathrm{MnCeO}_{\mathrm{x}}(\mathrm{E} / \mathrm{G})$ and $\mathrm{MnCeO}_{\mathrm{x}}(\mathrm{E} / \mathrm{C})$ were higher than $90 \%$, and the concentration of $\mathrm{HCHO}$ decreased to less than $0.8 \mathrm{mg} / \mathrm{m}^{3}$ over $36 \mathrm{~h}$, which was very important for the degradation of low concentration indoor HCHO. Similar with our previous result ${ }^{[44]}$, the present of stretching vibration of $\mathrm{C}-\mathrm{O}\left(\mathrm{v} \mathrm{CO}^{3-}\right)\left(1507.0 \mathrm{~cm}^{-1}\right)$ with carbonate or hydrocarbonate and the out-plane flexural vibration of absorbed $\mathrm{H}_{2} \mathrm{O}$ O-H (vo-H $)\left(1054.2 \mathrm{~cm}^{-1}\right)$ absorbing on the surface of $\mathrm{MnCeO}_{\mathrm{x}}$ can be detected by using IR spectrum, indicating that $\mathrm{HCHO}$ elimination was mainly catalytic oxidation including physical adsorption and the products of catalytic oxidation were $\mathrm{CO}_{2}$ and water. However, due to the low HCHO concentration $\left(1.05 \pm 0.05 \mathrm{mg} / \mathrm{m}^{3}\right)$, the reaction product of $\mathrm{CO}_{2}$ and $\mathrm{H}_{2} \mathrm{O}$ cannot be effectively detected in air. In comparison, the $\mathrm{MnCeO}_{\mathrm{x}}(\mathrm{W} / \mathrm{C})$ and $\mathrm{MnCeO}_{\mathrm{x}}(\mathrm{W} / \mathrm{G})$ catalysts prepared with water showed lower activity than ethanol. They reached HCHO oxidation of only $3.2 \%$ over $36 \mathrm{~h}$, especially for $\mathrm{MnCeO}_{\mathrm{x}}(\mathrm{W} / \mathrm{G})$ with the smallest surfaces, indicating that worst adsorption of $\mathrm{HCHO}$. The high adsorption and oxidation activity of catalysts mainly depended on the structure or abundant oxygen vacancies due to that these catalysts were synthesized with different solvents and complexing agents ${ }^{[33]}$.

Regarding $\mathrm{HCHO}$ oxidation, catalysts deactivation is still one the largest obstacles for applications in indoor $\mathrm{HCHO}$ purification at ambient temperature. Therefore, as shown in Fig. 2, the samples of $\mathrm{MnCeO}_{x}(\mathrm{C} / \mathrm{E})$ and $\mathrm{MnCeO}_{\mathrm{x}}(\mathrm{G} / \mathrm{E})$ were selected to evaluate the stability for three times. The results exhibited that these two kinds of catalysts for $\mathrm{HCHO}$ oxidation were stable with three consecutive tests without obvious activity decline. The HCHO concentrations were all lower than $0.08 \mathrm{mg} / \mathrm{m}^{3}$ over $36 \mathrm{~h}$ in all experiments. The degradation rate decreased slowly from $12 \mathrm{~h}$ to $48 \mathrm{~h}$ due to the decrease in physical absorption, but they exhibited almost the same activity as fresh catalysts, 
which was very important for the application in the low concentration indoor $\mathrm{HCHO}$.

Fig. 3 exhibits the conversion of $\mathrm{HCHO}$ as a function of time over an increasing $\mathrm{Ag}$ supported on $\mathrm{MnCeO}_{\mathrm{x}}(\mathrm{E} / \mathrm{C})$ and $\mathrm{MnCeO}_{\mathrm{x}}(\mathrm{E} / \mathrm{G})$ catalysts. Regarding the increasing $\mathrm{Ag}$ content over 1.0, 2.0, 5.0, 10.0 and $15.0 \mathrm{wt} \% \mathrm{Ag} / \mathrm{MnCeO}_{\mathrm{x}}$ catalysts, the actual $\mathrm{Ag}$ contents were $0.92,1.87,4.82,10.12$ and $15.15 \mathrm{wt} \%$, respectively, which was detected by using ICP-OES. The HCHO oxidation activities were improved constantly with the increase in $\mathrm{Ag}$, but the two kinds of catalysts with the highest activity showed a different loading of Ag. Fig. 3(A) shows that the activities of HCHO conversion over $\mathrm{Ag} / \mathrm{MnCeO}_{\mathrm{x}}(\mathrm{E} / \mathrm{C})$ increased with the growth of $\mathrm{Ag}$ loading. Consequently, the catalysts supported with $10.0 \mathrm{wt} \%$ or $15.0 \mathrm{wt} \%$ of Ag loading exhibited almost the same activities. More than $90 \%$ of $\mathrm{HCHO}$ conversion was achieved at ambient temperature over $24 \mathrm{~h}$, and the concentration of $\mathrm{HCHO}$ was less than $0.08 \mathrm{mg} / \mathrm{m}^{3}$. Considering economic cost, this study selected the catalysts with $10.0 \mathrm{wt} \%$ of Ag, which exhibited better activity, to investigate the stability. As shown in Fig. 3(B), the activity of $\mathrm{Ag} / \mathrm{MnCeO}_{\mathrm{x}}(\mathrm{E} / \mathrm{G})$ increased at first and decreased later with the increase in $\mathrm{Ag}$ The sample with $2.0 \mathrm{wt} \%$ of Ag exhibited the highest activity among these catalysts, about $92.4 \% \mathrm{HCHO}$ conversion over $24 \mathrm{~h}$, due to the effective activation of metallic silver. However, the activity decreased with increasing Ag loading, which could be interpreted by that the active sites of $\mathrm{MnCeO}_{x}(\mathrm{E} / \mathrm{G})$ were covered by more $\mathrm{Ag}$ and the performance of HCHO adsorption on the catalyst surface was constrained. Therefore, the amount of silver loading depended mainly on the different surface structure of $\mathrm{MnCeO}_{\mathrm{x}}(\mathrm{E} / \mathrm{C})$ and $\mathrm{MnCeO}_{\mathrm{x}}(\mathrm{E} / \mathrm{G})$ catalysts.

Extended time durability tests of $\mathrm{Ag} / \mathrm{MnCeO}_{\mathrm{x}}$ catalysts with different $\mathrm{Ag}$ loading and complexing agents are shown in Fig. 4. Both catalysts of $10.0 \mathrm{wt} \% \mathrm{Ag} / \mathrm{MnCeO}_{\mathrm{x}}(\mathrm{E} / \mathrm{C})$ and $2.0 \mathrm{wt} \% \mathrm{Ag} / \mathrm{MnCeO}_{\mathrm{x}}(\mathrm{E} / \mathrm{G})$ exhibited good stability after $192 \mathrm{~h}$ at ambient temperature. The HCHO concentration reduced from $1.05 \pm 0.05 \mathrm{mg} / \mathrm{m}^{3}$ to less than 0.08 $\mathrm{mg} / \mathrm{m}^{3}$ (EU standard) after $24 \mathrm{~h}$, which was $12 \mathrm{~h}$ shorter than $\mathrm{MnCeO}_{\mathrm{x}}$ catalysts without Ag loading. After multiple tests, both catalysts still maintained a high activity for HCHO degradation at ambient temperature similar as fresh catalysts, which was very important to apply in the low concentration indoor HCHO. 


\subsection{Catalysts characterization}

\subsection{1 $\mathrm{N}_{2}$ adsorption}

The textural properties, such as the specific surface areas, pore volumes, and average pore diameters of $\mathrm{MnCeO}_{\mathrm{x}}$ with different solvents (ethanol or water) and complexing agents were determined by $\mathrm{N}_{2}$ adsorption/desorption and the results were summarized in Table $1 . \mathrm{MnCeO}_{\mathrm{x}}$ catalysts synthesized with ethanol and citric acid showed larger pore volume and surface areas than the catalysts synthesized with water and glycol. Obviously, the pore volumes and surface areas of $\mathrm{MnCeO}_{\mathrm{x}}(\mathrm{E} / \mathrm{C})$ were more than double the values of $\mathrm{MnCeO}_{\mathrm{x}}(\mathrm{W} / \mathrm{C})$, except for the average pore diameters. The same result happened to the $\mathrm{MnCeO}_{\mathrm{x}}(\mathrm{W} / \mathrm{G})$ and $\mathrm{MnCeO}_{\mathrm{x}}(\mathrm{E} / \mathrm{G})$ catalysts, particularly for $\mathrm{MnCeO}_{\mathrm{x}}(\mathrm{W} / \mathrm{G})$, which exhibited that the smallest value with surface areas, pore volumes, and average pore diameters, possible due to the large sizes of particles. The results were well consistent with the following SEM. However, the sample of $\mathrm{MnCeO}_{\mathrm{x}}(\mathrm{E} / \mathrm{C})$ showed the highest surface areas $\left(78.3 \mathrm{~m}^{2} / \mathrm{g}\right)$, but the activity was lower than $\mathrm{MnCeO}_{\mathrm{x}}(\mathrm{E} / \mathrm{G})$. The above results displayed that the catalysts with the higher surface areas may not show the higher activity for $\mathrm{HCHO}$ oxidation and the surface area wasn't the only factor to improve the activity.

\subsubsection{Morphology of catalysts}

SEM images of $\mathrm{MnCeO}_{\mathrm{x}}$ synthesized by solvothermal method with the different solvents and complexing agents presented in Fig. 5(A)-(F). All these catalysts displayed a variational structural morphology due to different solvents, complexing agents and Ag loading. Regarding $\mathrm{MnCeO}_{\mathrm{x}}(\mathrm{W} / \mathrm{C})$ (Fig. 5(A)), the samples were different in shape and size and were mainly consists of irregular particles as activating oxides on the surface of the catalyst. However, as the complexing agents were replaced by glycol (Fig. 5(B)), strip particles appeared owing to the long-chain alkanes in glycol and a large number of spheroids , with size of $800 \mathrm{~nm}$. Moreover, these large sizes of strip particles and spheres were not conducive to improve the activities for $\mathrm{HCHO}$ oxidation. However, as the reactive solvent of deionized water was substituted by ethanol, the fine particulate matters with $\mathrm{MnCeO}_{\mathrm{x}}$ appeared and the sizes of these activity oxides exhibited only several nanometers in diameter, which was favorable for activity 
increase (Fig. 5(C)). The sample of $\mathrm{MnCeO}_{x}(\mathrm{E} / \mathrm{G})$ (Fig. 5(D)) show homogenous particles with curved sheet structure, which include a large amount of spherical particle with activities oxides on the surface. The diameter and thickness were about $2.0 \mu \mathrm{m}$ and $150 \mathrm{~nm}$, respectively. As shown in Fig. 5(E) and (F), the main structure was kept same as the above results in Fig. 5(C) and (D), but it was easy to find that some large stick of $\mathrm{Ag}$ existed in the sample of $10.0 \mathrm{wt} \% \mathrm{Ag} / \mathrm{MnCeO}_{\mathrm{x}}(\mathrm{E} / \mathrm{C})$ due to the higher $\mathrm{Ag}$ loading. However, for $2.0 \mathrm{wt} \% \mathrm{Ag} / \mathrm{MnCeO}_{\mathrm{x}}(\mathrm{E} / \mathrm{G})$, some small silk of $\mathrm{Ag}$ with high dispersion can be discovered, which was more important for the deep oxidation of $\mathrm{HCHO}$ due to the interaction between metallic $\mathrm{Ag}$ and $\mathrm{MnCeO}_{\mathrm{x}}$ at ambient temperature. The morphology and structure of these $\mathrm{MnCeO}_{\mathrm{x}}$ oxides could be confirmed from the high-resolution transmission electron micrographs (HRTEM). The images and EDS profiles were exhibited in Fig. 6. The $\mathrm{MnCeO}_{\mathrm{x}}(\mathrm{W} / \mathrm{G})$ exhibited a large amount of clubshaped activating oxides on the surface due to glycol. Regarding $\mathrm{MnCeO}_{\mathrm{x}}(\mathrm{E} / \mathrm{G})$ synthesized with ethanol through $\mathrm{H}_{2} \mathrm{O}$ replacing, they displayed spherical particles and $2.0 \mathrm{wt} \% \mathrm{Ag} / \mathrm{MnCeO}_{\mathrm{x}}(\mathrm{E} / \mathrm{G})$ showed mixed materials with club-shaped oxides and spherical particles. Meanwhile, a large amount of spherical Ag with high distribution could be found on the surface of club-shaped oxides, which was consistent with SEM and the following result of $\mathrm{H}_{2}$-TPR. HRTEM images further indicated that the lattice space of $0.32 \mathrm{~nm}$ could be identified as the (llll 11 ) diffraction planes of $\mathrm{CeO}_{2}$ over the sample of $\mathrm{MnCeO}_{\mathrm{x}}(\mathrm{W} / \mathrm{G})^{[40]}$, but manganese oxide still remained amorphous. However, the lattice spacing of 0.27 and $0.29 \mathrm{~nm}$ on the $\mathrm{MnCeO}_{\mathrm{x}}(\mathrm{E} / \mathrm{G})$ were attributed to the $(22$ 2) planes of $\mathrm{Mn}_{2} \mathrm{O}_{3}$ and $\left(\begin{array}{lll}0 & 1 & 1\end{array}\right)$ planes of $\mathrm{Ce}_{2} \mathrm{O}_{3}{ }^{[45]}$, respectively. In terms of $2.0 \mathrm{wt} \% \mathrm{Ag} / \mathrm{MnCeO}_{\mathrm{x}}(\mathrm{E} / \mathrm{G})$, the lattices spacing of 0.24 and $0.43 \mathrm{~nm}$ were assigned to

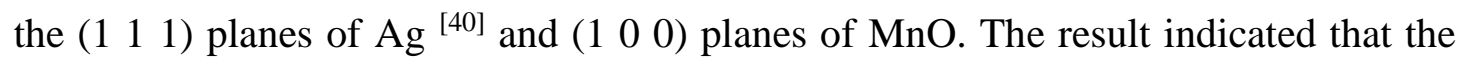
catalysts synthesized with ethanol showed more oxygen vacancies and lattice plane of low-valent manganese oxides attributed to the ethanol combustion could make higher synthetic temperature and consume large amounts of oxygen, which promoted the formation of $\mathrm{Mn}_{2} \mathrm{O}_{3}$ and $\mathrm{Ce}_{2} \mathrm{O}_{3}$. The significantly enhanced oxidation performance of $\mathrm{MnCeO}_{\mathrm{x}}(\mathrm{E} / \mathrm{G})$ could be ascribed to the abundant oxygen vacancies, which induced unsaturated oxygen species, such as $\mathrm{O}^{2-}, \mathrm{O}^{-}$and $\mathrm{OH}$ group. More importantly, regarding 
$2.0 \mathrm{wt} \% \mathrm{Ag} / \mathrm{MnCeO}_{\mathrm{x}}(\mathrm{E} / \mathrm{G})$, it was easy to find the existence of $\mathrm{MnO}$ attributed to the reduction of metal $\mathrm{Ag}$ from $\mathrm{Mn}_{2} \mathrm{O}_{3}$. This indicates the presence of more manganese vacancy, which could cause more unsaturated oxygen species, accordingly the enhanced activities of $\mathrm{Ag} / \mathrm{MnCeO}_{\mathrm{x}}(\mathrm{E} / \mathrm{G})$ for $\mathrm{HCHO}$ oxidation. Regarding the EDS profiles (Fig. 6(d)), there were $\mathrm{Mn}, \mathrm{Ce}, \mathrm{Ag}, \mathrm{O}$ and trace amounts of carbon in these samples and the molar ratio of atomic $\mathrm{Mn}$ and $\mathrm{Ce}, \mathrm{Mn}$ and $\mathrm{O}$, and $\mathrm{Ce}$ and $\mathrm{O}$ were 4.21, 0.49 , and 0.49 , respectively, which was agreed with the theoretical calculation value in the preparation of these catalysts and confirmed by the detection result of ICP-OES .

\subsubsection{Crystal structure}

Fig. 7 exhibits the $\mathrm{XRD}$ patterns of $\mathrm{MnCeO}_{\mathrm{x}}$ and $\mathrm{Ag} / \mathrm{MnCeO}_{\mathrm{x}}$ catalysts. $\mathrm{MnCeO}_{\mathrm{x}}(\mathrm{W} / \mathrm{C})$ and $\mathrm{MnCeO}_{\mathrm{x}}(\mathrm{W} / \mathrm{G})$ showed intense and sharp diffractions of $\mathrm{CeO}_{2}$ and $\mathrm{Ce}_{2} \mathrm{O}_{3}$, which were identified to the cubic fluorite structure (PDF \# 34-0394) and (PDF \# 44-1086), and manganese dioxides, such as $\mathrm{MnO}_{2}$ (PDF \# 50-0866) and $\mathrm{Mn}_{2} \mathrm{O}_{3}$ (PDF \# 41-1442). In terms of the structural features of $\mathrm{MnO}_{\mathrm{x}}-\mathrm{CeO}_{2}$, the results were slightly different from previous reports ${ }^{[45,46]}$. However, $\mathrm{MnCeO}_{\mathbf{x}}(\mathrm{E} / \mathrm{C})$ and $\mathrm{MnCeO}_{\mathrm{x}}(\mathrm{E} / \mathrm{G})$ displayed obviously weak and sharp diffractions, even amorphous state of $\mathrm{CeO}_{2}$ and $\mathrm{MnO}_{\mathrm{x}}$, due to the decreasing size of particulate matters and large fraction of mixed oxides. Regarding $\mathrm{Ag} / \mathrm{MnCeO}_{\mathrm{x}}$ catalysts, however, the significant XRD diffraction of $\mathrm{CeO}_{2}$, $\mathrm{Ce}_{2} \mathrm{O}_{3}, \mathrm{MnO}_{2}, \mathrm{Mn}_{2} \mathrm{O}_{3}$ and metallic $\mathrm{Ag}$ (PDF \# 04-0783) were found for $10.0 \mathrm{wt} \% \mathrm{Ag} / \mathrm{MnCeO}_{\mathrm{x}}(\mathrm{E} / \mathrm{C})$ due to the second highest temperature roasting at $550^{\circ} \mathrm{C}$. The results were consistent with those obtained by TEM. Owing to the low loading and high distribution of $\mathrm{Ag}$, the samples of $2.0 \mathrm{wt} \% \mathrm{Ag} / \mathrm{MnCeO}_{\mathrm{x}}(\mathrm{E} / \mathrm{G})$ didn't exhibit any sharp diffraction of $\mathrm{Ag}$ and only displayed weak diffraction peaks of cerium oxide and manganese oxide with different valences. This indicates the presence of cerium and manganese vacancy in the hybrid oxides, which induced unsaturated oxygen species nearby these vacancy, facilitated the formation of active oxygen species and accordingly obtained a high activity of HCHO degradation. 


\subsection{TG analysis}

The thermogravimetric analysis of $\mathrm{MnCeO}_{\mathrm{x}}$, and $\mathrm{Ag} / \mathrm{MnCeO}_{\mathrm{x}}$ catalysts from $30{ }^{\circ} \mathrm{C}$ to $500{ }^{\circ} \mathrm{C}$ are shown in Fig. 8. The $\mathrm{MnCeO}_{\mathrm{x}}$ catalysts of $\mathrm{MnCeO}_{\mathrm{x}}(\mathrm{W} / \mathrm{G}), \mathrm{MnCeO}_{\mathrm{x}}(\mathrm{E} / \mathrm{C})$, and $\mathrm{MnCeO}_{\mathrm{x}}(\mathrm{E} / \mathrm{G})$ didn't show obvious weight losses attributed to the low boiling point of ethanol and glycol, which could be decomposed during the treatment of these catalysts in the Teflon-lined autoclave at $120{ }^{\circ} \mathrm{C}$ for $24 \mathrm{~h}$. In addition, the high temperature in the autoclave further improved the decomposition of manganous nitrate and cerium nitrate into mixed oxides. Regarding $\mathrm{MnCeO}_{\mathrm{x}}(\mathrm{W} / \mathrm{C})$, there were five weight-loss regions could be observed. The two light weight losses $3.3 \mathrm{wt} \%$ and $2.4 \mathrm{wt} \%$ ) observed from $50^{\circ} \mathrm{C}$ to $150^{\circ} \mathrm{C}$ were assigned to the desorption of physically adsorbed molecular water ${ }^{[47]}$. The subsequent weight loss $(13.0 \mathrm{wt} \%)$ in the range of $200 \sim 255^{\circ} \mathrm{C}$ was ascribe to the decomposition of nitrates $\left(\mathrm{Mn}\left(\mathrm{NO}_{3}\right)_{2}\right.$ and $\left.\mathrm{Ce}\left(\mathrm{NO}_{3}\right)_{3}\right)$ into mixed oxides. An instantaneous weight loss $(42.8 \mathrm{wt} \%)$ at around $255^{\circ} \mathrm{C}$ was attributed to the carbonaceous compounds (citric acid) decomposition. The further weight loss $\left(6.7 \mathrm{wt} \%\right.$ ) between $255^{\circ} \mathrm{C}$ and $340^{\circ} \mathrm{C}$ was ascribed to the evaporation of residual carbon ${ }^{[48]}$. From the above results, it could be confirmed that the final calcination temperature at $550^{\circ} \mathrm{C}$ for $7 \mathrm{~h}$ have completely removed the carbon source. Regarding the samples of $\mathrm{Ag} / \mathrm{MnCeO}_{\mathrm{x}}$, there was a slight weight loss for the desorption of physically adsorbed water and the decomposition of silver nitrates into $\mathrm{Ag}$ (Fig. 8), and the $\mathrm{Ag} / \mathrm{MnCeO}_{\mathrm{x}}$ with high-loading silver also displayed a large weight loss.

\subsection{Raman analysis}

Owing to the sensitivity of crystal symmetry, Roman spectroscopy technique was recognized as an effective way to provide some additional structure information. The Raman spectra of $\mathrm{MnCeO}_{\mathrm{x}}$ and $\mathrm{Ag} / \mathrm{MnCeO}_{\mathrm{x}}$ catalysts are showed in Fig. 9. As for $\mathrm{MnCeO}(\mathrm{W} / \mathrm{C})$, a distinct $\mathrm{F}_{2 \mathrm{~g}}$ symmetry mode with the $\mathrm{CeO}_{2}$ phase at about $462 \mathrm{~cm}^{-1}$ was confirmed in the Raman spectra of $\mathrm{CeO}_{2}{ }^{[49]}$. Furthermore, a weak peak at around $600 \mathrm{~cm}^{-1}$ was identified to the oxygen vacancies, which was identified as $\mathrm{Ce}^{3+}$ ions. In addition, the $I_{600} / I_{462}$ value reflected the degree of the defect sites ${ }^{[50]}$, just as the relative content of oxygen vacancies. Moreover, the Raman spectrum showed a band at $631 \mathrm{~cm}^{-}$ ${ }^{1}$ attributed to Mn-O-Mn stretching mode ( $\left.v_{\mathrm{Mn}-\mathrm{O}-\mathrm{Mn}}\right)$ in $\mathrm{Mn}_{2} \mathrm{O}_{3}{ }^{[51,52]}$, denoting that $\mathrm{Mn}$ - 
$\mathrm{O}-\mathrm{Mn}$ was one of main structure in these catalysts. In addition, the intensity of $v_{\mathrm{Mn}-\mathrm{O}-\mathrm{Mn}}$ band with symmetry was almost the same, suggesting that Mn species widely distributed into cerium oxide and presented a highly asymmetric structure, for instance "Mn-O-Mn-O-Ce". The Raman peak at $438 \mathrm{~cm}^{-1}$ was identified as O-Mn-O stretching mode (v-Mn-O) in $\mathrm{MnO}_{2}$, which was in agreement with $\mathrm{XRD}$ for $\mathrm{MnCeO}_{\mathrm{x}}(\mathrm{E} / \mathrm{G})$ and $\mathrm{Ag} / \mathrm{MnCeO}_{\mathrm{x}}(\mathrm{E} / \mathrm{G}) . \mathrm{XRD}$ results also denoted that the main structure of $\mathrm{Ag} / \mathrm{MnCeO}_{\mathrm{x}}$ (E/G) is metallic silver, $\mathrm{MnO}_{2}, \mathrm{Mn}_{2} \mathrm{O}_{3}, \mathrm{CeO}_{2}$ and $\mathrm{Ce}_{2} \mathrm{O}_{3}$. This was attributed to that $\mathrm{Mn}$ atomic orbit wasn't same as $\mathrm{Ce}$ and $\mathrm{O}$ atoms, which was located in a perturbed chemical surrounding. As a result, $\mathrm{O}$ atoms indicated with high moving, and therefore $\mathrm{MnO}_{2}$ species can be disintegrated into $\mathrm{Mn}_{2} \mathrm{O}_{3}$ and $\mathrm{MnO}$ via oxygen removal. These oxygens were provided to metallic silver to form $\mathrm{Ag}_{2} \mathrm{O}{ }^{[53]}$. Therefore, the improved activity of $\mathrm{Ag} / \mathrm{MnCeO}_{\mathrm{x}}$ catalysts was probably the result of synergistic effect through oxygen moving.

\subsection{XPS characterization}

Fig. 10 shows the XPS spectra of Mn 2p, Ce 3d, O 1s and $\mathrm{Ag} 3 \mathrm{~d}$ in the samples of $\mathrm{MnCeO}_{\mathrm{x}}(\mathrm{E} / \mathrm{G})$ and $2.0 \mathrm{wt} \% \mathrm{Ag} / \mathrm{MnCeO}_{\mathrm{x}}(\mathrm{E} / \mathrm{G})$. The binding energy at ca. 640.5, 641.9, and $643.7 \mathrm{eV}$ corresponded to $\mathrm{Mn}^{2+}, \mathrm{Mn}^{3+}$, and $\mathrm{Mn}^{4+}$, respectively (Fig. 10(A)). Owing to $\mathrm{Ag}$ loading, the concentration of $\mathrm{Mn}^{4+}$ on $2.0 \mathrm{wt} \% \mathrm{Ag} / \mathrm{MnCeO}_{\mathrm{x}}(\mathrm{E} / \mathrm{G})$ decreased, but $\mathrm{Mn}^{2+}$ increased. Some researchers reported that high concentration of $\mathrm{Mn}^{4+}$ could cause oxygen vacant sites ${ }^{[44,50]}$. Therefore, a higher ratio of $\mathrm{Mn}^{4+}$ over $\mathrm{MnCeO}_{\mathbf{x}}(\mathrm{E} / \mathrm{G})$ may result in more oxygen vacancies, which may be a way to improve the activity for catalytic oxidation of $\mathrm{HCHO}$. Compared with $\mathrm{MnCeO}_{x}(\mathrm{E} / \mathrm{G})$, the $\mathrm{Mn} 2 \mathrm{p}$ level in the $2.0 \mathrm{wt} \% \mathrm{Ag} / \mathrm{MnCeO}_{\mathrm{x}}(\mathrm{E} / \mathrm{G})$ oxide migrated slightly to larger values, indicating the strong interaction between $\mathrm{Ag}$ and $\mathrm{MnCeO}_{\mathrm{x}}{ }^{[54]}$. The $\mathrm{Ce} 3 \mathrm{~d}$ spectra of $\mathrm{MnCeO}_{\mathrm{x}}(\mathrm{E} / \mathrm{G})$ and $2.0 \mathrm{wt} \% \mathrm{Ag} / \mathrm{MnCeO}_{\mathrm{x}}(\mathrm{E} / \mathrm{G})$ are shown in Fig. 10(B). It was easy to find that the binding energy of $\mathrm{Ce}^{4+}$ and $\mathrm{Ce}^{3+}$ on the sample of $2.0 \mathrm{wt} \% \mathrm{Ag} / \mathrm{MnCeO}_{\mathrm{x}}(\mathrm{E} / \mathrm{G})$ exhibited higher than the sample of $\mathrm{MnCeO}_{\mathrm{x}}(\mathrm{E} / \mathrm{G})$. As reported in references ${ }^{[55,56]}$, the $\mathrm{Ce}^{4+}$ was fitted with the peaks at approximately $\mathrm{v}_{1}, \mathrm{v}_{2}, \mathrm{v}_{3}, \mathrm{v}_{4}, \mathrm{v}_{5}$, and $\mathrm{v}_{6}$, and the peaks at $\mathrm{u}_{1}$ and $\mathrm{u}_{2}$ were attributed to $\mathrm{Ce}^{3+}$. Obviously, the concentration of $\mathrm{Ce}^{3+}$ on the $2.0 \mathrm{wt} \%$ $\mathrm{Ag} / \mathrm{MnCeO}_{\mathrm{x}}(\mathrm{E} / \mathrm{G})$ was higher than that on the $\mathrm{MnCeO}_{\mathrm{x}}(\mathrm{E} / \mathrm{G})$. Moreover, the higher 
concentration of $\mathrm{Ce}^{3+}$ can promote more oxygen vacancies ${ }^{[55,56]}$, which will be produces to keep electrostatic balance, as following:

$$
4 \mathrm{Ce}^{4+}+\mathrm{O}^{2-} \rightarrow 4 \mathrm{Ce}^{4+}+2 e / \square+0.5 \mathrm{O}_{2} \rightarrow 2 \mathrm{Ce}^{4+}+2 \mathrm{Ce}^{3+}+\square+0.5 \mathrm{O}_{2}
$$

Where $\square$ indicated an empty position from the removal of $\mathrm{O}^{2-}$, represented as an oxygen tetrahedral site $\left(\mathrm{Ce}_{4} \mathrm{O}\right)$. The electrostatic balance depended on the reduction of two different cerium cations $\left(\mathrm{Ce}^{4+}\right.$ and $\left.\mathrm{Ce}^{3+}\right)$. The above result indicated that $2.0 \mathrm{wt} \%$ $\mathrm{Ag} / \mathrm{MnCeO}_{\mathbf{x}}(\mathrm{E} / \mathrm{G})$ included more oxygen vacancies and showed a higher activity for HCHO oxidation.

As shown in Fig. $10(\mathrm{C})$, the $\mathrm{O}$ 1s spectra of $\mathrm{MnCeO}_{\mathrm{x}}$ oxides were fit into two peaks: surface adsorbed oxygen $\left(\mathrm{O}_{\text {ads }}\right)$ at $531.3 \mathrm{eV}$ and lattice oxygen $\left(\mathrm{O}_{\text {latt }}\right)$ at $529.8 \mathrm{eV}^{[51]}$. The $\mathrm{O} 1 \mathrm{~s}$ peak of adsorbed molecular water $\left(\mathrm{O}_{\text {wat }}\right)$ at $532.7 \mathrm{eV}$ has not been discovered. The $\mathrm{O}_{\text {ads }} /\left(\mathrm{O}_{\text {latt }}+\mathrm{O}_{\text {ads }}\right)$ decreased from $31.9 \%$ to $29.4 \%$ with the Ag loading, indicating that $\mathrm{MnCeO}_{\mathrm{x}}(\mathrm{E} / \mathrm{G})$ was rich in surface adsorbed oxygen. Owing to the high mobility of $\mathrm{O}_{\mathrm{ads}}$, the $\mathrm{MnCeO}_{\mathrm{x}}(\mathrm{E} / \mathrm{G})$ probably show higher activity than $2.0 \mathrm{wt} \% \mathrm{Ag} / \mathrm{MnCeO}_{\mathrm{x}}$ (E/G), but the final result mainly depends on its facile reducibility of metallic silver ${ }^{[57]}$. In order to further inspect the electronic state of Ag on the catalyst surface, the XPS spectra of $\mathrm{Ag} 3 \mathrm{~d}$ on $2.0 \mathrm{wt} \% \mathrm{Ag} / \mathrm{MnCeO}_{\mathrm{x}}(\mathrm{E} / \mathrm{G})$ was measured and exhibited in Fig. 10(D). No spectra of $\mathrm{Ag} 3 \mathrm{~d}$ could be detected on $\mathrm{MnCeO}_{\mathrm{x}}(\mathrm{E} / \mathrm{G})$. However, it was easy to find two peaks at $373.9 \mathrm{eV}\left(\mathrm{Ag} 3 \mathrm{~d}_{3 / 2}\right)$ and $367.9 \mathrm{eV}\left(\mathrm{Ag} 3 \mathrm{~d}_{5 / 2}\right)$, which were close to those expected for metallic silver $(374.0 \mathrm{eV} \text { and } 368.0 \mathrm{eV})^{[58]}$, indicating that the $\mathrm{Ag}$ on $\mathrm{MnCeO}_{\mathrm{x}}(\mathrm{E} / \mathrm{G})$ mainly existed with the metallic state ${ }^{[59]}$. The result was confirmed by the thermal decomposition of $\mathrm{Ag}_{2} \mathrm{O}^{[60]}$. $\mathrm{Ag}_{2} \mathrm{O}$ can be decomposed into metallic silver at a temperature above $400{ }^{\circ} \mathrm{C}$ but lower than $550{ }^{\circ} \mathrm{C}$ on the preparation of the catalyst. The high reducibility of metallic silver was very important for $2.0 \mathrm{wt} \%$ $\mathrm{Ag} / \mathrm{MnCeO}_{\mathrm{x}}(\mathrm{E} / \mathrm{G})$ to increase the oxygen mobility and improve activity of $\mathrm{HCHO}$ oxidation at ambient temperature.

\section{6 $\mathrm{H}_{2}-\mathrm{TPR}$ characterization}

The $\mathrm{H}_{2}$-TPR curves of the $\mathrm{MnCeO}_{\mathrm{x}}$ catalysts synthesized with different solvents and complexing agents were displayed in Fig. 11. Among these five catalysts, the 
$\mathrm{MnCeO}_{\mathrm{x}}(\mathrm{E} / \mathrm{G})$ exhibited the largest $\mathrm{H}_{2}$ consumption, followed by $\mathrm{MnCeO}_{\mathrm{x}}(\mathrm{E} / \mathrm{C})$, $2 \mathrm{wt} \% \mathrm{Ag} / \mathrm{MnCeO}_{\mathrm{x}}(\mathrm{E} / \mathrm{G}), \mathrm{MnCeO}_{\mathrm{x}}(\mathrm{W} / \mathrm{G})$ and $\mathrm{MnCeO}_{\mathrm{x}}(\mathrm{W} / \mathrm{C})$, (Fig. 11). Regarding $\mathrm{MnCeO}_{\mathrm{x}}(\mathrm{W} / \mathrm{C})$, the reduction started at $250{ }^{\circ} \mathrm{C}$ and a broad peak concentrated at $550^{\circ} \mathrm{C}$ was probably attributed to the reduction of lattice and surface oxygen of $\mathrm{MnO}_{2}$ and $\mathrm{CeO}_{2}$. Meanwhile, $\mathrm{MnCeO}_{\mathrm{x}}(\mathrm{W} / \mathrm{G})$ exhibited a similar reduction profile with the same reduction temperature at $550^{\circ} \mathrm{C}$, but an inconspicuous broad peak at $445^{\circ} \mathrm{C}$ could also be discovered and ascribed to the reduction from $\mathrm{MnO}_{2}$ to $\mathrm{Mn}_{2} \mathrm{O}_{3}{ }^{[38,50]}$. In terms of $\mathrm{MnCeO}_{\mathrm{x}}(\mathrm{E} / \mathrm{C})$ and $\mathrm{MnCeO}_{\mathrm{x}}(\mathrm{E} / \mathrm{G})$, there were apparent peaks at $445^{\circ} \mathrm{C}$ due to the reduction from $\mathrm{MnO}_{2}$ to $\mathrm{Mn}_{2} \mathrm{O}_{3}$, and the peaks at $550{ }^{\circ} \mathrm{C}$ were recognized as a further reduction from $\mathrm{Mn}_{2} \mathrm{O}_{3}$ to $\mathrm{MnO}$. The above result was confirmed by the strong interplay between $\mathrm{MnO}_{\mathrm{x}}$ and $\mathrm{CeO}_{2}$ species, which formed into a solid solution and provide more active oxygen to increase the redox ability. In the meantime, the redox of these catalysts depended on the structures, such as the surface areas, the sizes and the distributions of these activity oxides ${ }^{[14]}$. It is noteworthy that the sample of $2.0 \mathrm{wt} \% \mathrm{Ag} / \mathrm{MnCeO}_{\mathrm{x}}(\mathrm{E} / \mathrm{G})$ including two reduction peaks at around $225^{\circ} \mathrm{C}$ and $300{ }^{\circ} \mathrm{C}$ was the most reducible due to the metallic silver loading. $\mathrm{MnCeO}_{\mathrm{x}}$ oxides with $\mathrm{Ag}$ loading reduced the reduction temperature and improved the activities of $\mathrm{HCHO}$ oxidation. The shift of reduction temperature to a lower temperature indicated that the metallic silver facilitated the reduction with these surface oxygen species. This might be attributed to a more weakening of the $\mathrm{Mn}-\mathrm{O}$ bond due to that metallic silver promoted the formation of more low-cost manganese oxide ${ }^{[54,61]}$, which were in agreement with XRD and TEM.

\section{$3.7 \mathrm{O}_{2}-\mathrm{TPD}$ characterization}

$\mathrm{O}_{2}$-TPD profiles of different $\mathrm{MnCeO}_{\mathrm{x}}$ and $\mathrm{Ag} / \mathrm{MnCeO}_{\mathrm{x}}$ catalysts are exhibited in Fig.

12. It was demonstrated that the active oxygen on the surface of these catalysts, such as $\mathrm{O}_{2}{ }^{-}$and $\mathrm{O}^{-}$, desorbed at relatively lower temperature, while lattice oxygen desorbed at higher temperature ${ }^{[62]}$. Therefore, the peaks of oxygen desorption with lower temperatures at $142,155,176,272$ and $369{ }^{\circ} \mathrm{C}$ could be regarded as surface active oxygen; and these peaks of oxygen desorption at around 515, 590, 626, 670, 683, 715, 718, 744 and $748{ }^{\circ} \mathrm{C}$ could be assigned to lattice oxygen desorption from $\mathrm{MnO}_{\mathrm{x}}$ and $\mathrm{CeO}_{2}$. Compare with $\mathrm{MnCeO}_{\mathrm{x}}(\mathrm{W} / \mathrm{G})$ and $\mathrm{MnCeO}_{\mathrm{x}}(\mathrm{E} / \mathrm{G})$, the $\mathrm{MnCeO}_{\mathrm{x}}$ catalysts, such 
as $\mathrm{MnCeO}_{\mathrm{x}}(\mathrm{W} / \mathrm{C})$ and $\mathrm{MnCeO}_{\mathrm{x}}(\mathrm{E} / \mathrm{C})$, showed a larger amount of surface active oxygen and lower lattice oxygen. Among these samples, $\mathrm{MnCeO}_{\mathrm{x}}(\mathrm{W} / \mathrm{G})$ showed the lowest activity of $\mathrm{HCHO}$ oxidation because of that $\mathrm{MnCeO}_{\mathrm{x}}(\mathrm{W} / \mathrm{G})$ displayed the lowest surface active oxygen and relatively lower lattice oxygen species. Furthermore, on the basis of the synergistic effect with lattice oxygen and surface active oxygen ${ }^{[39]}$, the sample of $2.0 \mathrm{wt} \% \mathrm{Ag} / \mathrm{MnCeO}_{\mathrm{x}}(\mathrm{E} / \mathrm{G})$ displayed a relatively low surface oxygen desorption peak, but high lattice oxygen. Therefore, the $2.0 \mathrm{wt} \% \mathrm{Ag} / \mathrm{MnCeO}_{\mathrm{x}}(\mathrm{E} / \mathrm{G})$ exhibited higher activity than the other kinds of $\mathrm{MnCeO}_{\mathrm{x}}$ catalysts. These results implied that Ag doping would facilitate the generation of more surface active oxygen and these catalysts with more surface active oxygen and lattice oxygen would improve the activities for $\mathrm{HCHO}$ degradation at ambient temperature.

\subsection{Plausible oxygen transfer mechanism of $\mathrm{Ag} / \mathrm{MnCeO}$ catalysts}

More importantly, the $\mathrm{HCHO}$ complete oxidation on $\mathrm{Ag} / \mathrm{MnCeO}_{\mathrm{x}}(\mathrm{E} / \mathrm{G})$ catalysts within only $24 \mathrm{~h}$ was finished at the temperature as low as ambient temperature, indicating that a synergetic effect with metallic $\mathrm{Ag}, \mathrm{MnO}_{2}, \mathrm{Mn}_{2} \mathrm{O}_{3}, \mathrm{CeO}_{2}$ and $\mathrm{Ce}_{2} \mathrm{O}_{3}$, which were identified by XRD, TEM and XPS. This interaction could be deduced as an oxygen shift mechanism ascribed to the oxygen mobility, as follow ${ }^{[54]}$ :

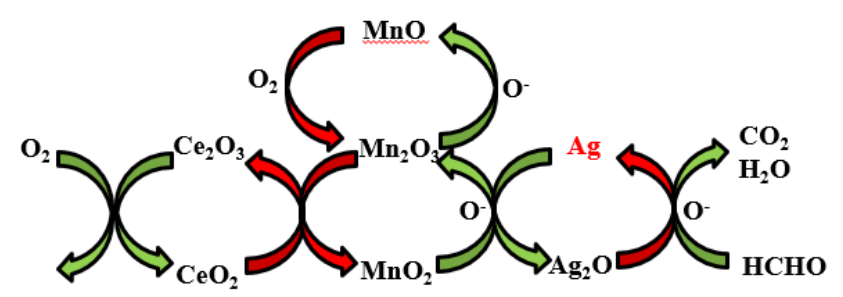

At first, the metallic silver was oxidized to $\mathrm{Ag}_{2} \mathrm{O}$ through the oxygen from $\mathrm{MnO}_{2}$, the oxygen species obtained from the $\mathrm{Ag}_{2} \mathrm{O}$ decomposition participated in $\mathrm{HCHO}$ degradation ${ }^{[63,64]}$. And then, the regeneration from $\mathrm{Mn}_{2} \mathrm{O}_{3}$ to $\mathrm{MnO}_{2}$, and from $\mathrm{MnO}_{2}$ to $\mathrm{MnO}$ were completed from the oxygen supplier of $\mathrm{CeO}_{2}$. In the meantime, the formed $\mathrm{Ce}_{2} \mathrm{O}_{3}$ was re-oxidized into $\mathrm{CeO}_{2}$ by $\mathrm{O}_{2}$. Therefore, metallic silver, cerium oxide and manganese oxide with different valences were all very important to improve the oxygen mobility and increase activity at ambient temperature. These abundant cerium and manganese vacancies promoted the forming of unsaturated oxygen species, which improved the activity for HCHO oxidation. 


\section{Conclusions}

(1) $\mathrm{MnCeO}_{\mathrm{x}}$ were synthesized by solvothermal method with different solvents and complexing agents, including water or ethanol, and citric acid or glycol. They were investigated for catalytic oxidation of formaldehyde at ambient temperature under a real indoor environment, low concentration of indoor formaldehyde $\left(1.0 \pm 0.5 \mathrm{mg} / \mathrm{m}^{3}\right)$ and static air condition. The developed catalysts synthesized with ethanol showed high surface areas after the solvothermal treatment. The result demonstrated that a large amount of fine particulate matters with more $\mathrm{MnCeO}_{\mathrm{x}}$ oxides appeared and the sizes exhibited only several nanometers in diameter. These oxides developed into a hybrid oxides with different valences of cerium and manganese oxides, which could provide more active oxygen to increase the redox ability.

(2) The structure of $\mathrm{MnCeO}_{\mathrm{x}}$ oxides can be controlled by regulating both solvent and complexing agents, which was an effective method to promote the performance of these catalysts at ambient temperature.

(3) The developed $\mathrm{Ag} / \mathrm{MnCeO}_{\mathrm{x}}$ catalysts exhibited better activity towards $\mathrm{HCHO}$ decomposition at ambient temperature due to the high reducibility/distribution of metallic silver and weak the surface $\mathrm{Mn}-\mathrm{O}$ bond. This increased the surface oxygen and improved the oxygen mobility. The strong interplay between $\mathrm{Ag}$ and $\mathrm{MnCeO}_{\mathrm{x}}$ greatly affected the performance.

(4) Compared with $\mathrm{MnCeO}_{\mathrm{x}}$ catalysts, the time for complete oxidation of low concentration of $\mathrm{HCHO}$ to less than $0.08 \mathrm{mg} / \mathrm{m}^{3}$ over $\mathrm{Ag} / \mathrm{MnCeO}_{\mathrm{x}}$ catalysts decreased from $36 \mathrm{~h}$ to $24 \mathrm{~h}$. And these catalysts displayed good stability with a series of tests, indicating that they can be manufactured as efficient catalysts for indoor pollution removal.

\section{Acknowledgments}

This work was financially supported by the Natural Science Foundation of Jiangsu Province (Nos. BK20170954 and BK20150890), the National Natural Science Foundation of China (Nos. 21501097), the Qing Lan Project of the Jiangsu Higher Education Institutions of China, the Priority Academic Program Development of 
Jiangsu Higher Education Institutions (PAPD), the Top-notch Academic Programs Project of Jiangsu Higher Education Institutions (PPZY2015C222), the Jiangsu Engineering Technology Research Centre of Environmental Cleaning Materials and Open fund by Jiangsu Key Laboratory of Atmospheric Environment Monitoring and Pollution Control (KHK1806), A Project Funded by the Priority Academic Program Development of Jiangsu Higher Education Institutions (PAPD).

Conflict of interest: We declare that we do not have any commercial or associative interest that represents a conflict of interest in connection with the work submitted.

\section{References}

[1] Zhang CB, He H, Tanaka K. Catal. Commun. 6(2005): 211-214.

[2] Nie LH, Yu JG, Jaroniec M, Tao FF. Catal. Sci. Technol. 6(2016): 3649-3669.

[3] Yang H. Nature 509(2014): 535-535.

[4] Yang H, Flower RJ, Thompson JR. Nature 560(2018):167-167.

[5] Huang Q, Ma WJ, Yan XK, Chen YW, Zhu SM, Shen SB. J. Mol. Catal. A 366(2013): 261-265.

[6] Yang H, Ma M, Thompson JR, Flower RJ. J. Epidemiol. Commun. H. 72(2018): 237-243.

[7] Zhang CB, Li YB, Wang YF, He H. Environ. Sci. Technol. 48(2014): 5816-5822.

[8] Wang ZQ, Pei JJ, Zhang JS. Build. Environ. 65(2013): 49-57.

[9] Zhao DZ, Li XS, Shi C, Fan HY, Zhu AM. Chem. Eng. J. 66(2011): 3922-3929.

[10] Park SJ, Bae I, Nam IS, Cho BK, Jung SM, Lee JH. Chem. Eng. J. 195-196 (2012) 392-402.

[11] Kim M, Park E, Jurng J. Powder. Technol. 325 (2018) 368-372.

[12] Chen BB, Zhu XB, Crocker M, Wang Y, Shi C. Catal. Commun. 42(2013): 93-97.

[13] Zhang L, Chen L, Li YB, Peng YX, Chen F, Wang L, Zhang CB, Meng XJ, He H, Xiao FS. Appl. Catal. B: Environ. 219(2017): 200-208.

[14] Huang HB, Leung DYC. J. Catal. 280(2011): 60-67.

[15] Kwona DW, Seo PW, Kim GJ, Hong SC. Appl. Catal. B: Environ. 163 (2015) 436-443.

[16] Dewil R, Everaert K, Baeyens J. Catal. Commun. 6 (2005) 793-795.

[17] Kim GJ, Lee SM, Hong SC, Kim SS. RSC. Adv. 8 (2018) 3626-3636.

[18] An NH, Wu P, Lia SY, Jia MJ, Zhang WX. Appl. Surf. Sci. 285(2013): 805-809.

[19] An NH, Yu QS, Liu G, Li SY, Jia MJ, Zhang WX. J. Hazard. Mater. 186(2011): 1392-1397.

[20] Wang LF, Sakurai M, Kameyama H. J. Hazard. Mater. 167(2009): 399-405.

[21] Kim SS, Park KH, Hong SC. Appl. Catal. A: Gel. 398(2011): 96-103.

[22] Zhang CB, He H, Tanaka K. Appl. Catal. B: Environ. 65(2006): 37-43.

[23] Peng JX, Wang SD. Appl. Catal. B: Environ. 73(2007): 282-291.

[24] Liu BT, Hsieh CH, Wang WH, Huang CC, Huang CJ. Chem. Eng. J. 232(2013): 434-441.

[25] Wang LF, Zhang Q, Sakurai M , H. Kameyama H. Catal. Commun. 8(2007): 2171-2175.

[26] Huang HB, Leung DYC, Ye DQ. J. Mater. Chem. 21(2011): 9647-652.

[27] Zhang CB, He H. Catal. Today. 126(2007): 345-350.

[28] Zhang J, Jin Y, Li CY, Shen YN, Han L, Hu ZX, Di XW, Liu ZL. Appl. Catal. B: Environ. 91(2009): 11-20. 
[29] Liu BC, Li CY, Zhang YF, Liu Y, Hu WT, Wang Q, Han L, Zhang J. Appl. Catal. B: Environ. 111-112(2012): 467-475.

[30] Chen BB, Shi C, Crocker M, Wang Y, Zhu AM. Appl. Catal. B: Environ. 132-133(2013): 245255.

[31] An NH, Zhang WL, Yuan XL, Pan B, Liu G, Jia MJ, Yan WF, Zhang WX. Chem. Eng. J. 215216(2013): 1-6.

[32] Tian H, He JH, Zhang XD, Zhou L, Wang DH. Microporous. Mesoporous. Mate. 138(2011): $118-122$.

[33] Tang XF, Chen JL, Huang XM, Xu YD, Shen WJ. Appl. Catal. B: Environ. 81(2008): 115-121.

[34] Tang XF, Li YG, Huang XM, Xu YD, Zhu HQ, Wang JG, Shen WJ. Appl. Catal. B: Environ. 62(2006): 265-273.

[35] Qu ZP, Shen SK, Chen D, Wang Y. J. Mol. Catal. A. 356(2012): 171-177.

[36] Torres JQ, Giraudon JM, Lamonier JF. Catal. Today. 176(2011): 277-280.

[37] Sidheswaran MA, Destaillats H, Sullivan DP, Larsen J, Fisk WJ. Appl. Catal. B: Environ. 107(2011): 34-41.

[38] Tian H, He JH, Liu LL, Wang DH, Hao ZP, Ma CY. Microporous. Mesoporous. Mate. 151(2012): 397-402.

[39] Ma L, Wang DS, Li JH, Bai BY, Fu LX, Li YD. Appl. Catal. B: Environ. 148-149(2014): 3643.

[40] Lamova TK, Mamontov G, Salaev M, Zaikovskii V, Popova G, Sobolev V, Knyazev A, Vodyankina O. Appl. Catal. A: Gel. 467(2013): 519-529.

[41] Chen D, Qu ZP, Zhang WW, Li XY, Zhao QD, Shi Y. Colloid. Surf. A-Physicochem. Eng. Asp. 379(2011): 136-142.

[42] Wen YR, Tang X, Li JH, Hao JM, Wei LS, Tang XF. Catal. Commun. 10(2009): 1157-1160.

[43] Wang Y, Zhu AM, Chen BB, Crocker M, Shi C. Catal. Commun. 36(2014): 52-57.

[44] Huang Q, Lu YY, Si H, Yang B, Tao T, Zhao YX, Chen MD. Catal. Lett. 148(2018): 28802890.

[45] Liao YN, Fu ML, Chen LM, Wu JL, Huang BC, Ye DQ. Catal. Today. 216(2013): 220-228.

[46] Wang XY, Kang Q, Li D. Appl. Catal. B: Environ. 86(2009): 166-175.

[47] He C, Yu YK, Shi JW, Shen Q, Chen JS, Liu HX. Mater. Chem. Phys. 157(2015): 87-100.

[48] Huang Q, Wang Q, Tao T, Zhao YX, Wang P, Ding ZY, Chen MD. Environ Technol (2018) doi: 10.1080/09593330.2018.1432700.

[49] Wang W, Zhu Q, Dai QG, Wang XY. Chem. Eng. J. 307(2017): 1037-1046.

[50] Zhao P, Wang CG, He F, Liu ST. RSC. Adv. 4(2014): 45665-45672.

[51] Dai Y, Wang XY, Li D, Dai QG. J. Hazard. Mater. 188 (2011): 132-139.

[52] Cai T, Huang H, Deng W, Dai QG, Liu W, Wang XY. Appl. Catal. B: Environ. 166-167(2015): 393-405.

[53] Dai Y, Wang XY, Dai QG, Li D. Appl. Catal. B: Environ. 111-112(2012): 141-149.

[54] Tang XF, Chen JL, Li YG, Li Y, Xu YD, Shen WJ. Chem. Eng. J. 118(2006): 119-125.

[55] Liu XW, Zhou KB, Wang L, Wang BY, Li YD. J. Am. Chem. Soc. 131(2009): 3140-3141.

[56] Zhang Y, Chen MX, Zhang ZX, Jiang Z, Shangguan WF, Einaga H. Catal. Today. 327(2019): 323-333.

[57] Lu SH, Wang X, Zhu QY, Chen CC, Zhou XF, Huang FL, Li KL, He LL, Liu YX, Pang FJ. RSC. Adv. 8(2018): 14221-14228. 
[58] Stathatos E, Lianos P, Falaras P, Siokou A. Langmuir 16(2000): 2398-2400.

[59] Zhang JH, Li YB, Zhang Y, Chen M, Wang L, Zhang CB, He H. Sci. Rep. 5(2015): 1295012959.

[60] Waterhouse GIN, Bowmaker GA, Metson JB. Phys Chem. Chem. Phys. 3(2001): 3838-3845.

[61] Hamoudi S, Sayari A, Belkacemi K, Bonneviot L, Larachi F. Catal. Today. 62(2000): 379-388.

[62] Ma CY, Wang DH, Xue WJ, Dou BJ, Wang HL, Hao ZP. Environ. Sci. Technol. 45(2011): $3628-3634$.

[63] Andreasen A, Lynggaard H, Stegelmann C, Stoltze P. Surf. Sci. 544(2003): 5-23.

[64] Kundakovic L, Flytzani-Stephanopoulos M. Appl. Catal. A: Gel. 183(1999): 35-51.

\section{Tables}

Table 1. The specific surface areas, pore volumes, and average pore diameters of $\mathrm{MnCeO}_{\mathrm{x}}$ catalysts

\begin{tabular}{cccc}
\hline Sample & Surface area $\left(\mathrm{m}^{2} / \mathrm{g}\right)$ & Pore volume $\left(\mathrm{cm}^{3} / \mathrm{g}\right)$ & Average pore diameters $(\mathrm{nm})$ \\
\hline $\mathrm{MnCeO}_{\mathrm{x}}(\mathrm{W} / \mathrm{C})$ & 36.7 & 0.083 & 3.84 \\
$\mathrm{MnCeO}_{\mathrm{x}}(\mathrm{W} / \mathrm{G})$ & 8.4 & 0.009 & 1.92 \\
$\mathrm{MnCeO}_{\mathrm{x}}(\mathrm{E} / \mathrm{C})$ & 78.3 & 0.150 & 3.58 \\
$\mathrm{MnCeO}_{\mathrm{x}}(\mathrm{E} / \mathrm{G})$ & 25.9 & 0.052 & 3.82 \\
\hline
\end{tabular}




\section{Figure captions}

Fig. 1. Catalytic performance of different $\mathrm{MnCeO}_{\mathrm{x}}$ catalysts for $\mathrm{HCHO}$ oxidation

Fig. 2. The durability of different $\mathrm{MnCeO}_{\mathrm{x}}$ catalysts for $\mathrm{HCHO}$ oxidation at ambient temperature

Fig. 3. Catalytic performance of different loading of $\mathrm{Ag}$ supported on $\mathrm{MnCeO}_{\mathrm{x}}$ for $\mathrm{HCHO}$ oxidation

Fig. 4. The durability of $\mathrm{Ag} / \mathrm{MnCeO}_{\mathrm{x}}$ catalysts for $\mathrm{HCHO}$ oxidation at ambient temperature

Fig. 5. $\mathrm{SEM}$ images of (A): $\mathrm{MnCeO}_{\mathrm{x}}(\mathrm{W} / \mathrm{C}),(\mathrm{B}): \mathrm{MnCeO}_{\mathrm{x}}(\mathrm{W} / \mathrm{G}),(\mathrm{C}): \mathrm{MnCeO}_{\mathrm{x}}(\mathrm{E} / \mathrm{C}),(\mathrm{D})$ : $\mathrm{MnCeO}_{\mathrm{x}}(\mathrm{E} / \mathrm{G}),(\mathrm{E}): 10.0 \mathrm{wt} \% \mathrm{Ag} / \mathrm{MnCeO}_{\mathrm{x}}(\mathrm{E} / \mathrm{C})$, and $(\mathrm{F}): 2.0 \mathrm{wt} \% \mathrm{Ag} / \mathrm{MnCeO}_{\mathrm{x}}(\mathrm{E} / \mathrm{G})$

Fig. 6. TEM images and EDS profiles of (a): $\mathrm{MnCeO}_{\mathrm{x}}(\mathrm{W} / \mathrm{G}),(\mathrm{b}): \mathrm{MnCeO}_{\mathrm{x}}(\mathrm{E} / \mathrm{G})$, and (c): $2.0 \mathrm{wt} \% \mathrm{Ag} / \mathrm{MnCeO}_{x}(\mathrm{E} / \mathrm{G})$

Fig. 7. $\mathrm{XRD}$ patterns of different $\mathrm{MnCeO}_{\mathrm{x}}$ and $\mathrm{Ag} / \mathrm{MnCeO}_{\mathrm{x}}$ catalysts

Fig. 8. $\mathrm{TG}$ profiles of different $\mathrm{MnCeO}_{\mathrm{x}}$ and $\mathrm{Ag} / \mathrm{MnCeO}_{\mathrm{x}}$ catalysts

Fig. 9. Raman spectra of different $\mathrm{MnCeO}_{x}$ and $\mathrm{Ag} / \mathrm{MnCeO}_{\mathrm{x}}$ catalysts

Fig. 10. XPS spectra of 1: $\mathrm{MnCeO}_{\mathrm{x}}(\mathrm{E} / \mathrm{G}), 2: 2.0 \mathrm{wt} \% \mathrm{Ag} / \mathrm{MnCeO}_{\mathrm{x}}(\mathrm{E} / \mathrm{G}):(\mathrm{A}) \mathrm{Mn} 2 \mathrm{p}$; (B) Ce 3d; (C) $\mathrm{O} 1 \mathrm{~s}$ and (D) $\mathrm{Ag} \mathrm{3d}$

Fig. 11. $\mathrm{H}_{2}$-TPR profiles of different $\mathrm{MnCeO}_{\mathrm{x}}$ and $\mathrm{Ag} / \mathrm{MnCeO}_{\mathrm{x}}$ catalysts

Fig. 12. $\mathrm{O}_{2}$-TPD profiles of (a): $\mathrm{MnCeO}_{\mathrm{x}}(\mathrm{W} / \mathrm{C}),(\mathrm{b}): \mathrm{MnCeO}_{\mathrm{x}}(\mathrm{W} / \mathrm{G}),(\mathrm{c}): \mathrm{MnCeO}_{\mathrm{x}}(\mathrm{E} / \mathrm{C}),(\mathrm{d})$ : $\mathrm{MnCeO}_{\mathrm{x}}(\mathrm{E} / \mathrm{G})$ and $(\mathrm{e}): 2.0 \mathrm{wt} \% \mathrm{Ag} / \mathrm{MnCeO}_{\mathrm{x}}(\mathrm{E} / \mathrm{G})$ 


\section{Figures}

Fig. 1

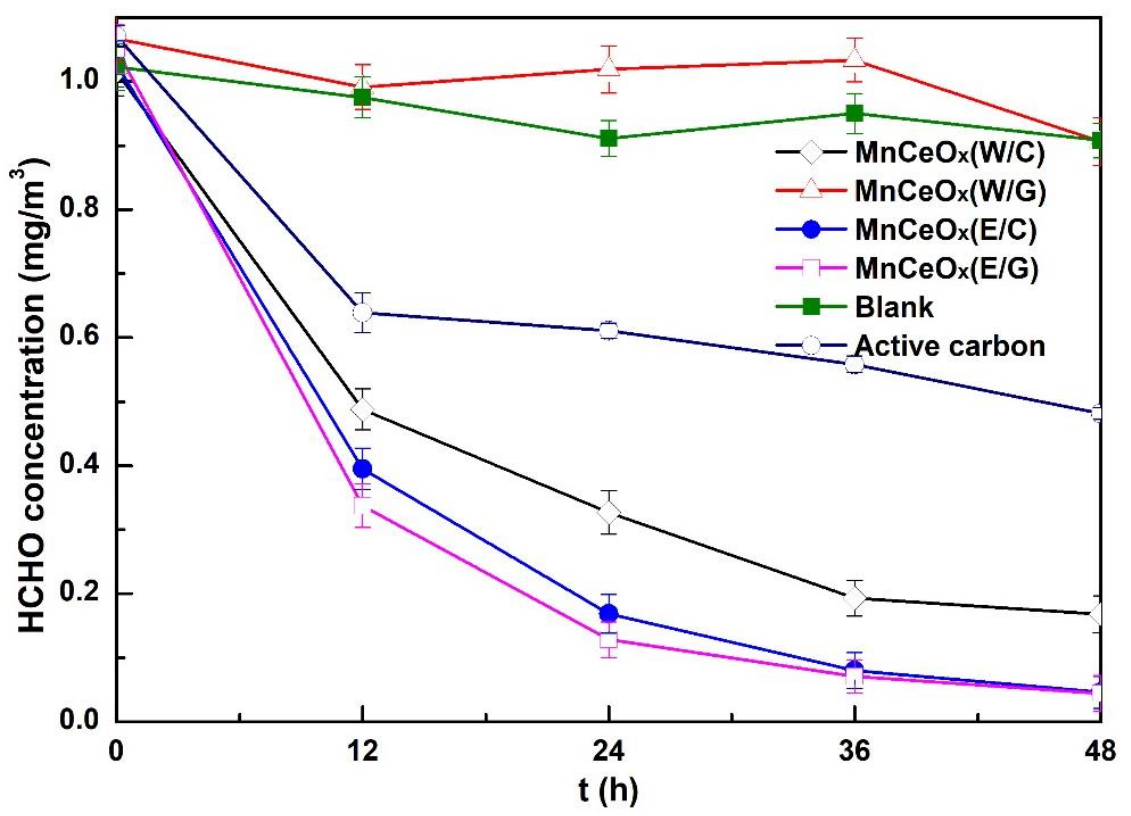


Fig. 2

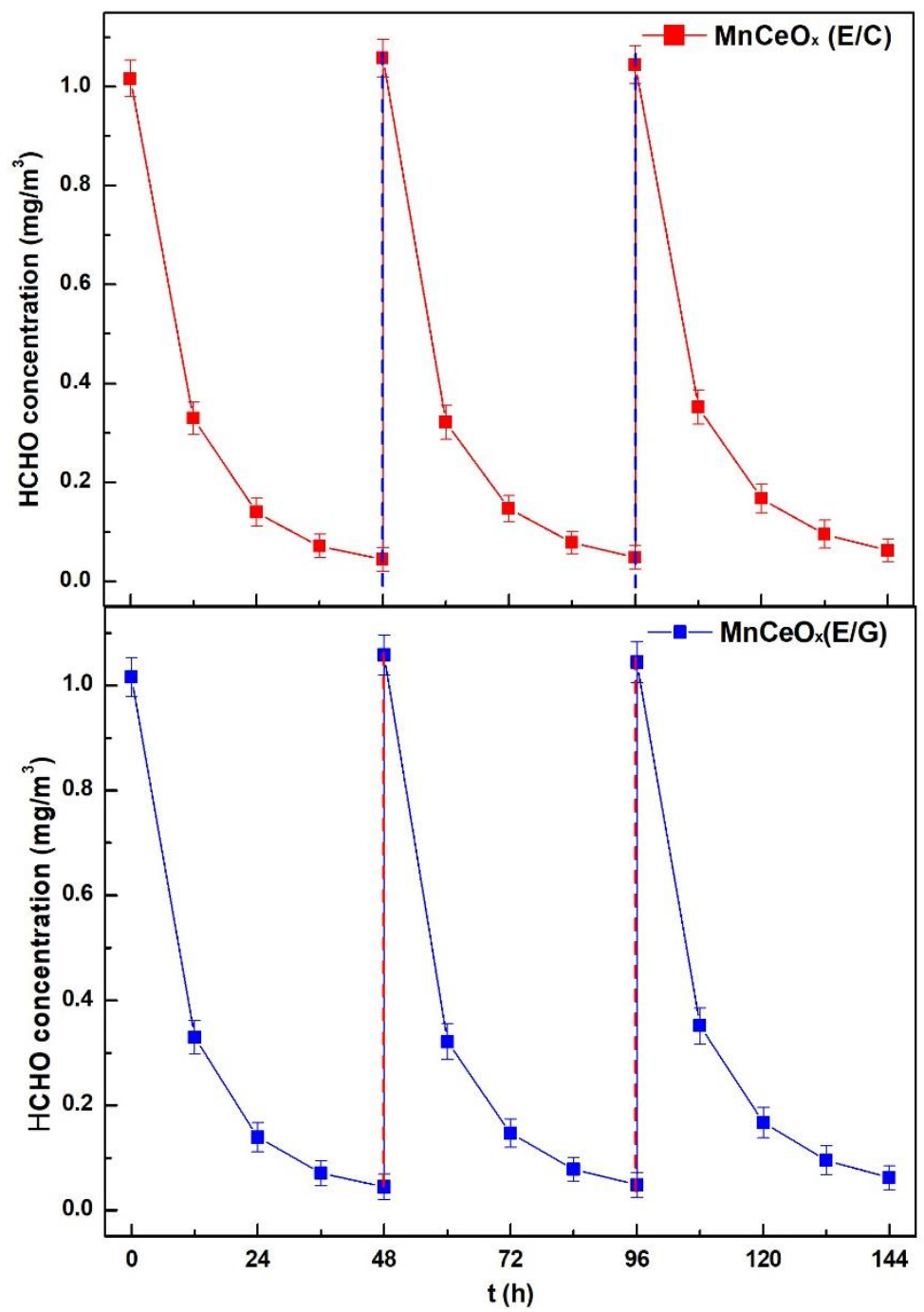


Fig. 3
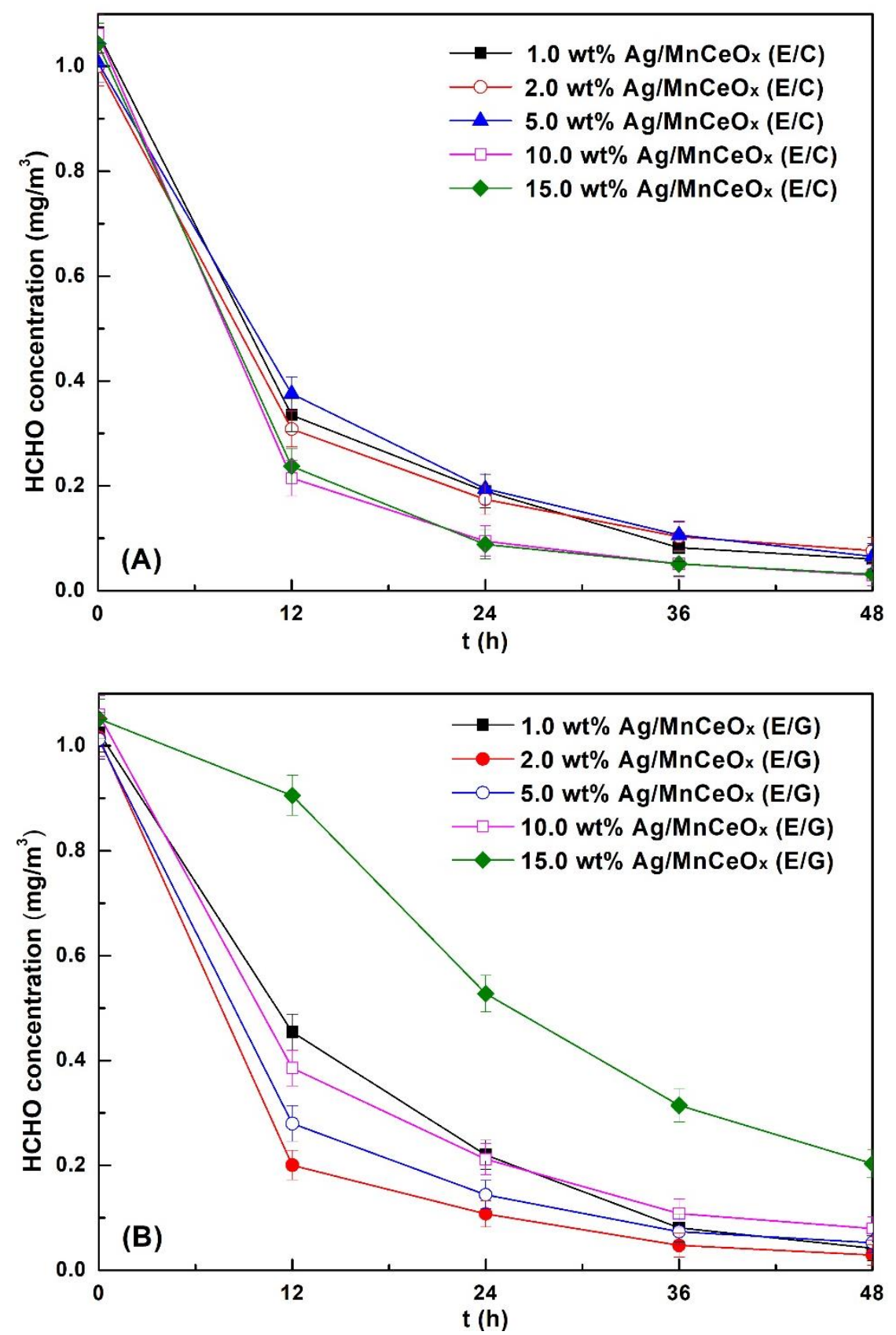
Fig. 4

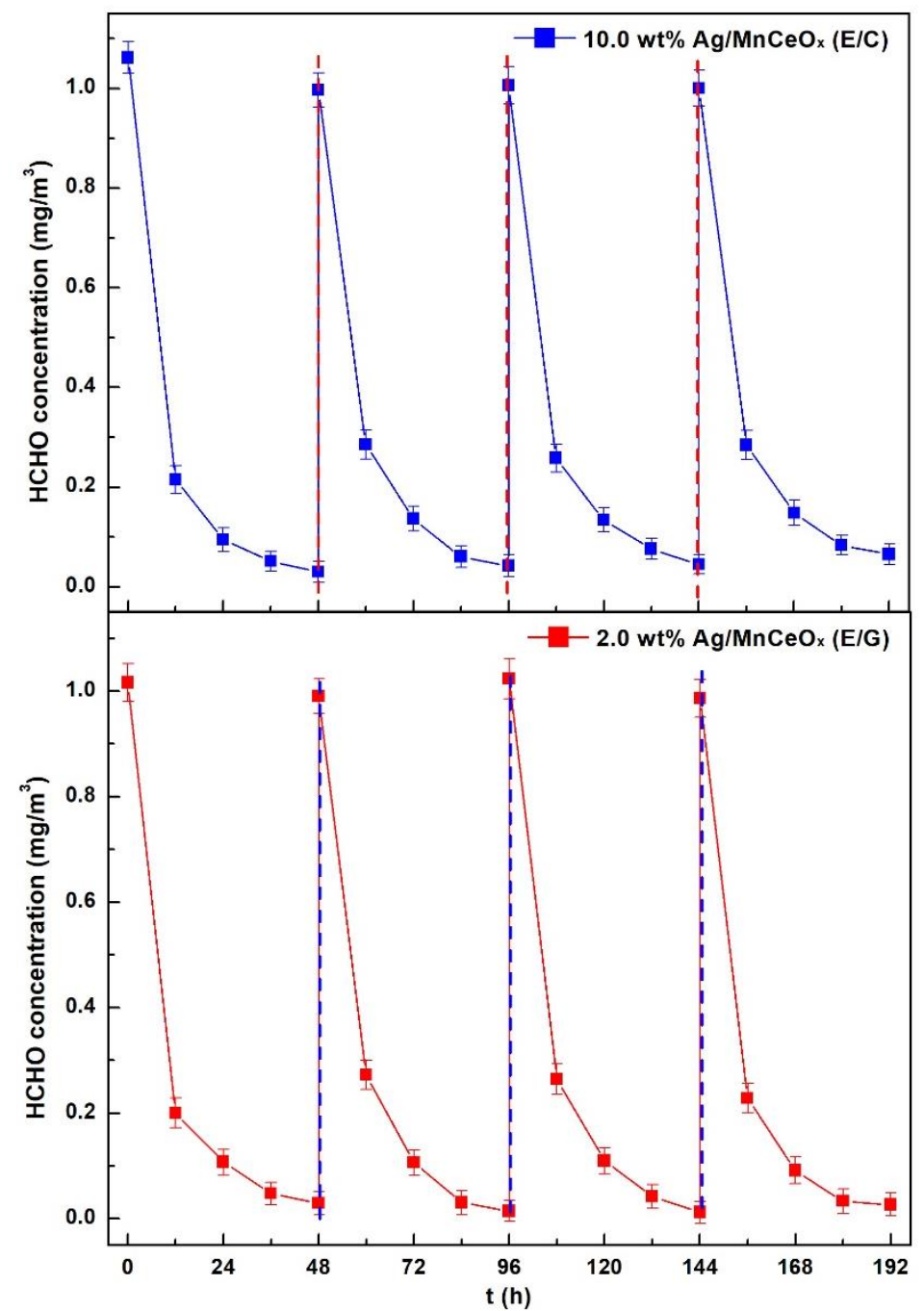


Fig. 5
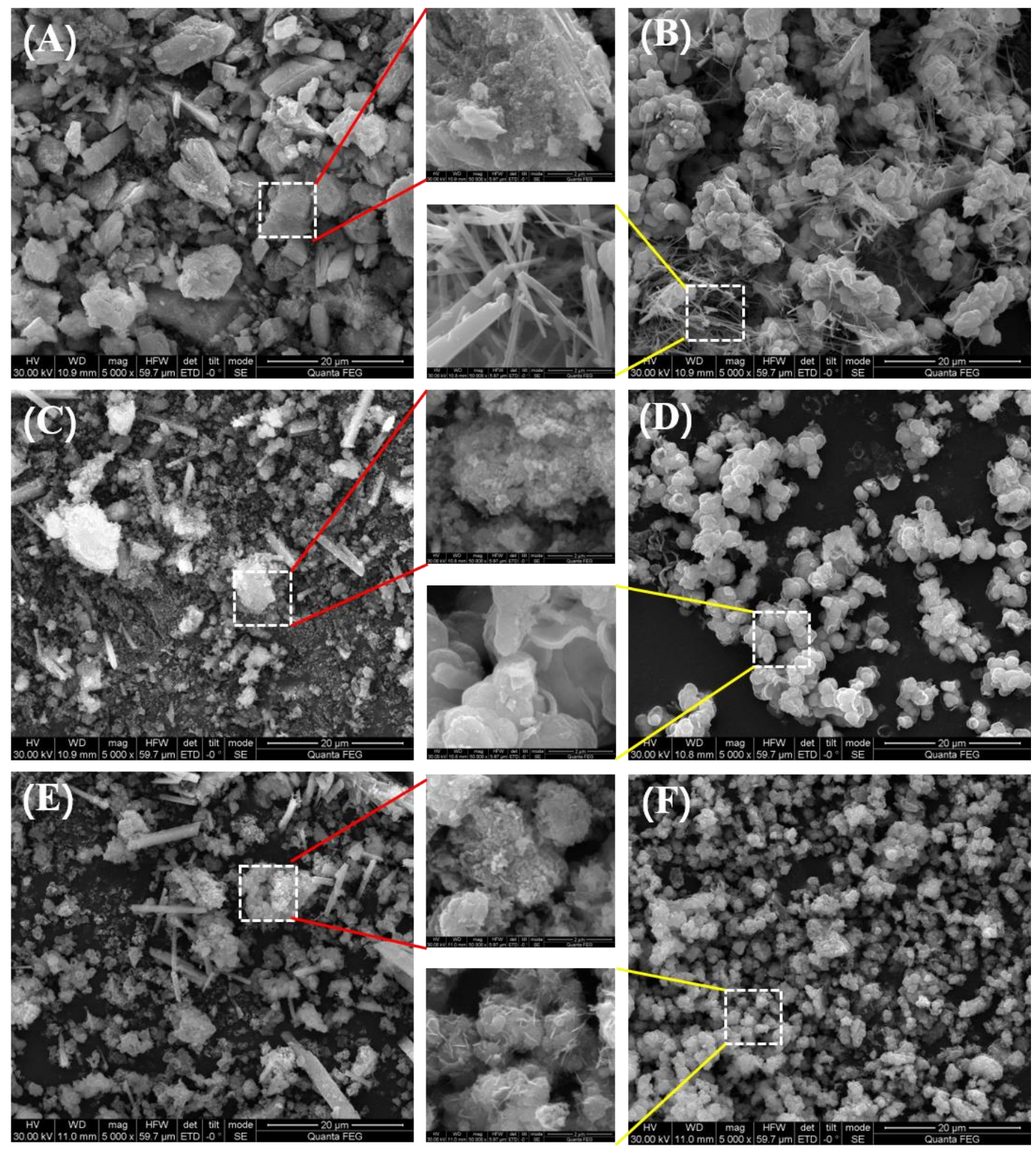
Fig. 6
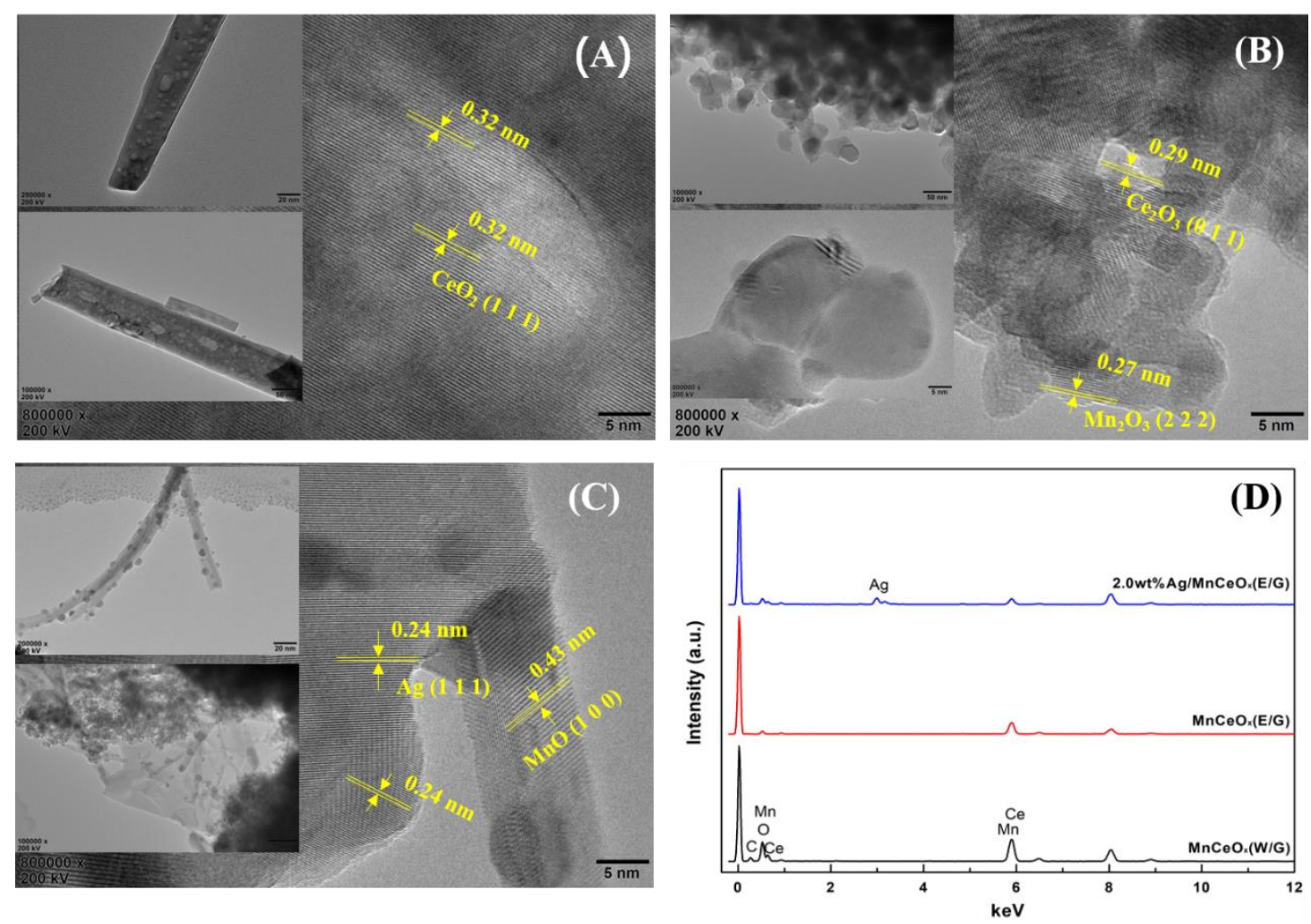
Fig. 7

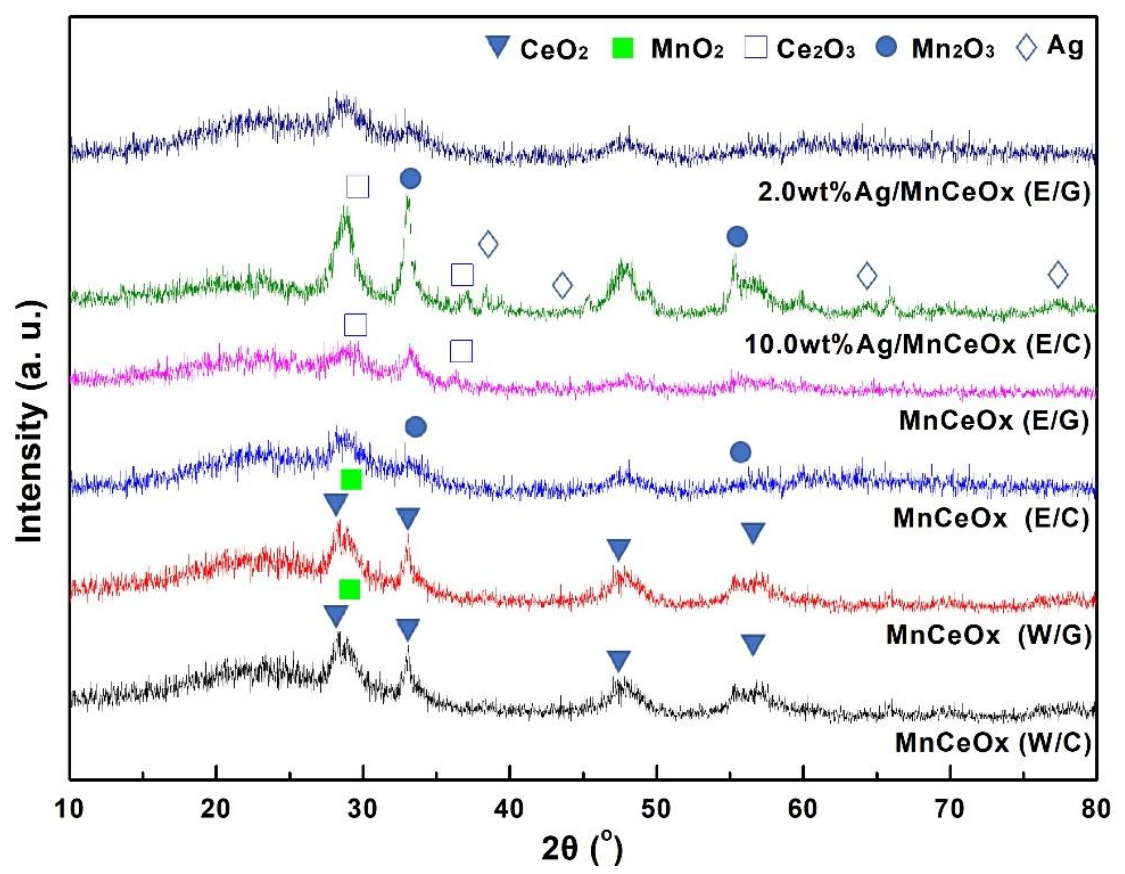


Fig. 8

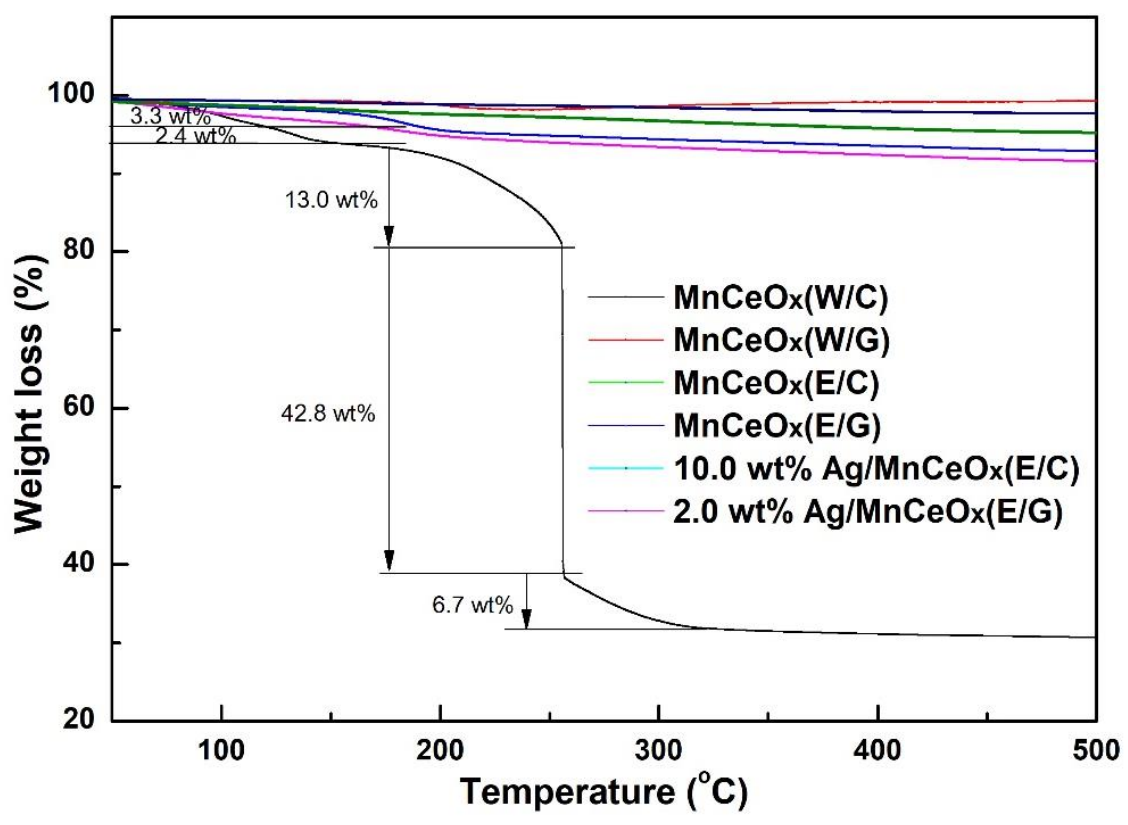


Fig. 9

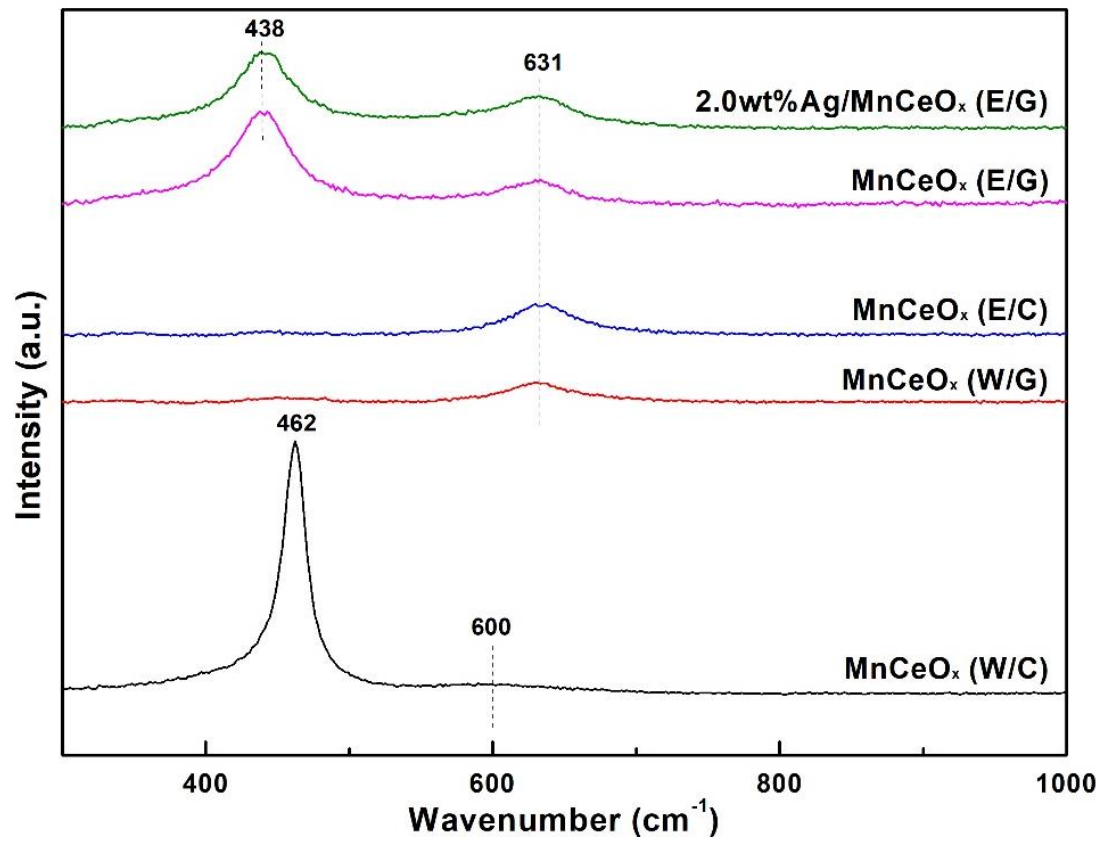


Fig. 10
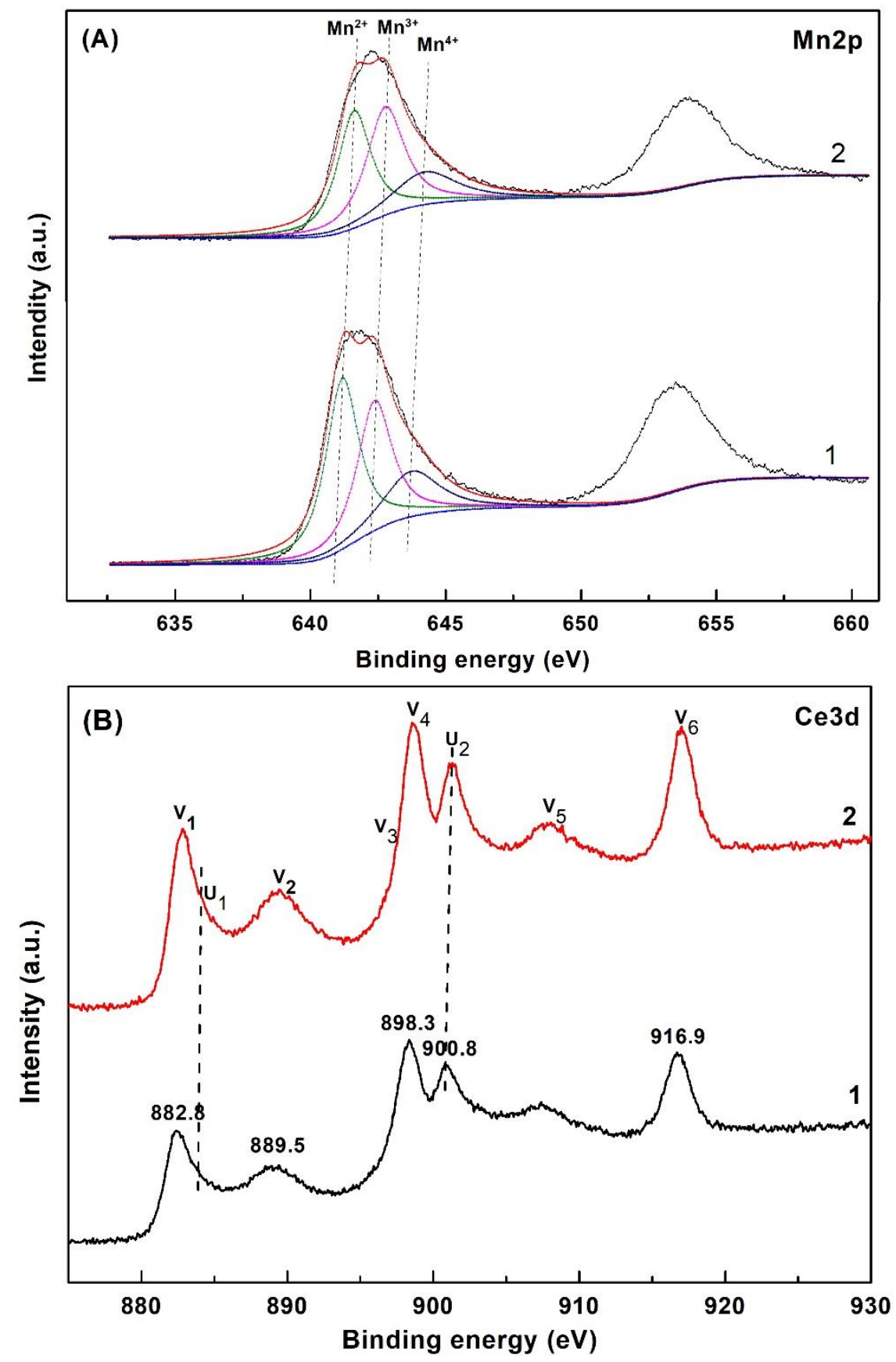

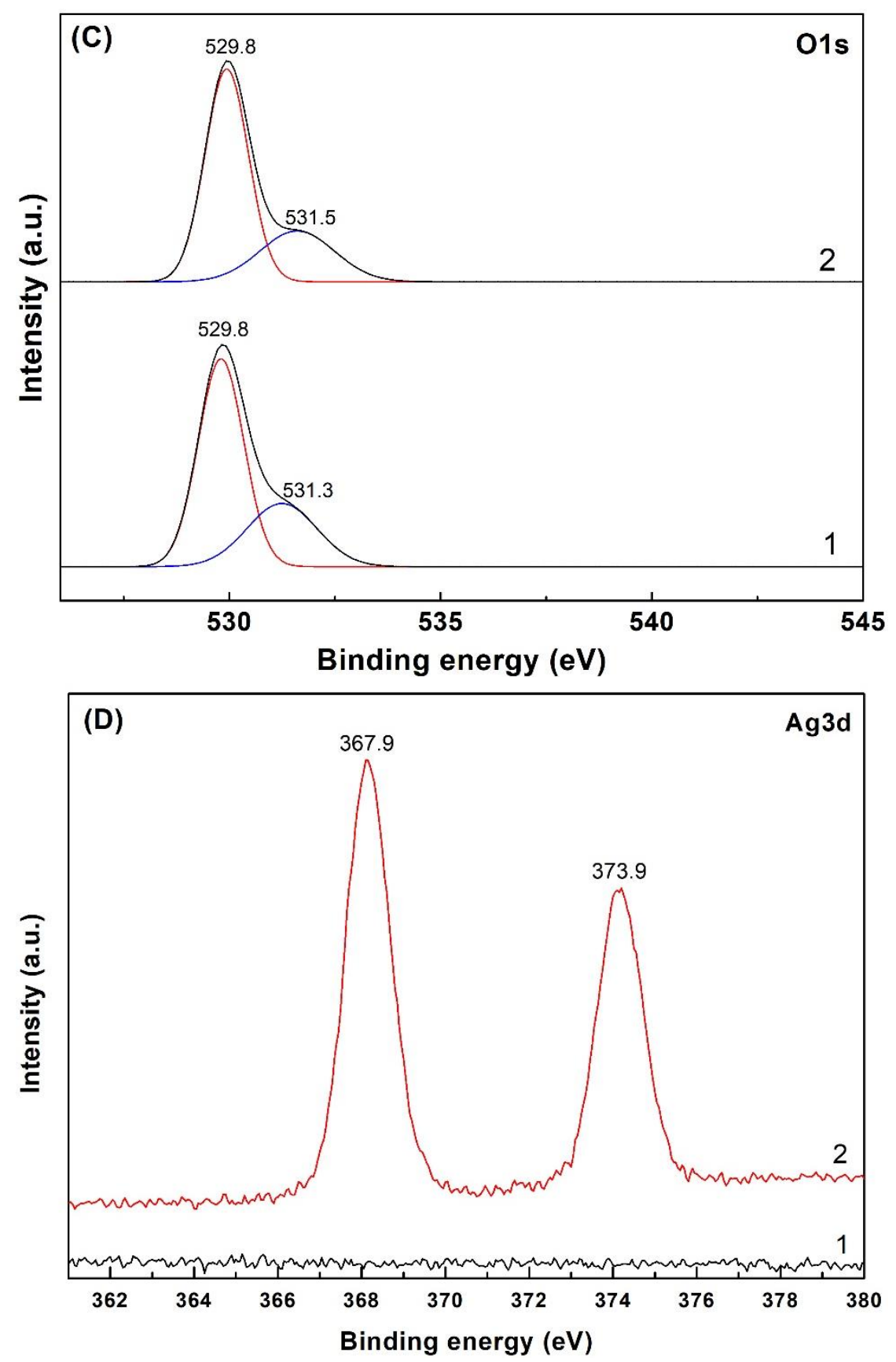
Fig. 11

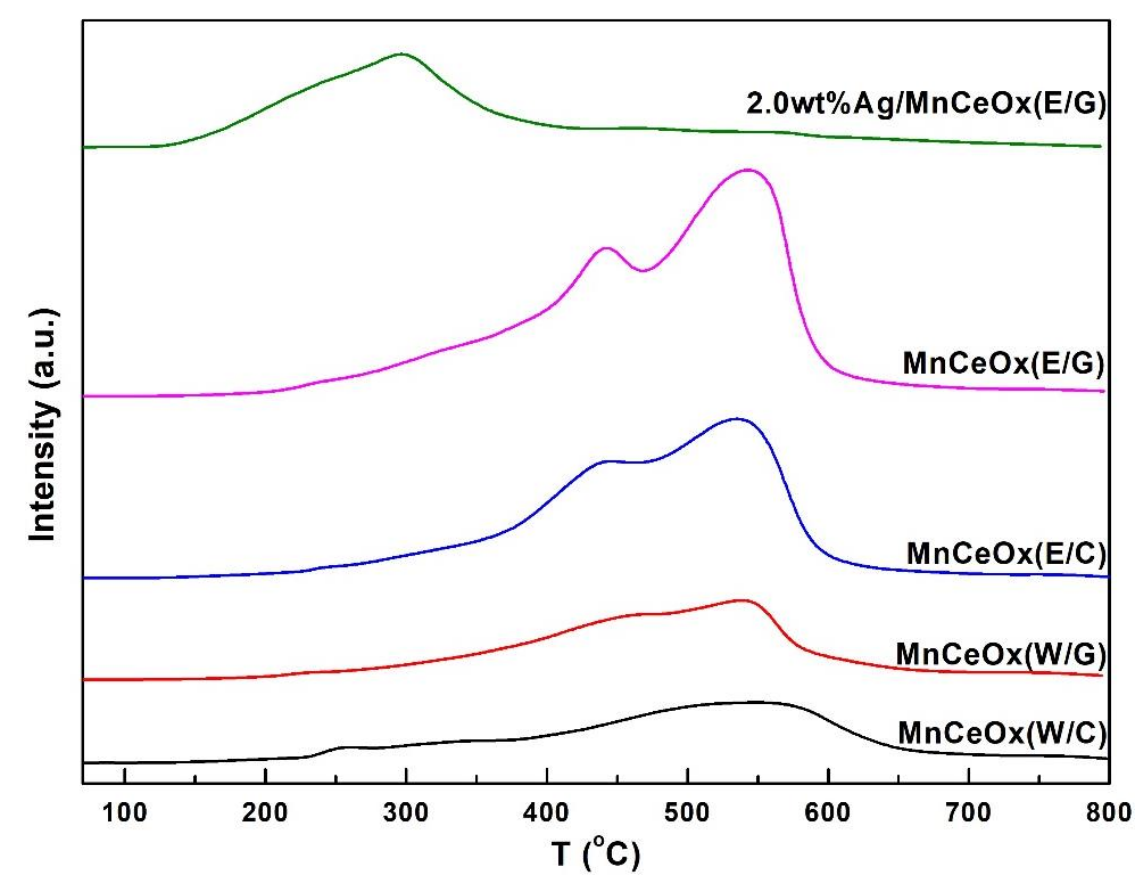


Fig. 12

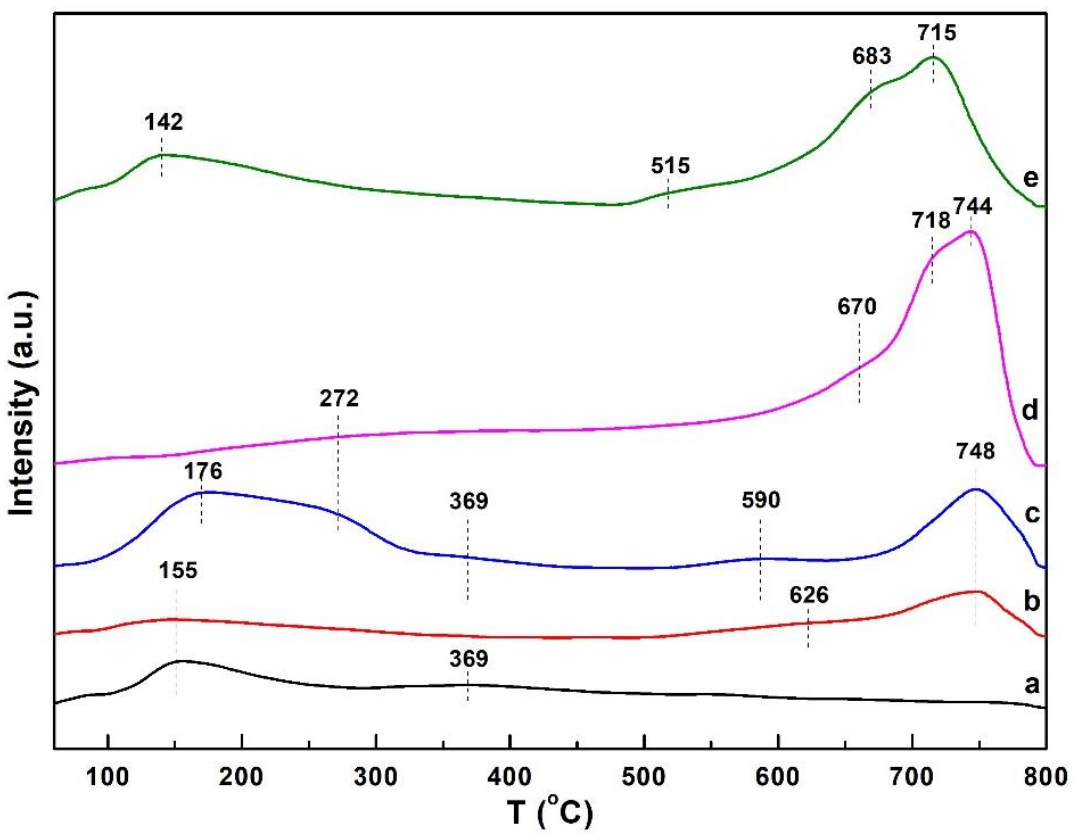

